Portland State University

PDXScholar

6-11-1997

\title{
Structural and Successional Analysis of Woodland Vegetation in Tualatin Hills Nature Park
}

Christopher J. Dobson

Portland State University

Follow this and additional works at: https://pdxscholar.library.pdx.edu/open_access_etds

Part of the Biology Commons

Let us know how access to this document benefits you.

\section{Recommended Citation}

Dobson, Christopher J., "Structural and Successional Analysis of Woodland Vegetation in Tualatin Hills Nature Park" (1997). Dissertations and Theses. Paper 5825.

https://doi.org/10.15760/etd.7696

This Thesis is brought to you for free and open access. It has been accepted for inclusion in Dissertations and Theses by an authorized administrator of PDXScholar. Please contact us if we can make this document more accessible: pdxscholar@pdx.edu. 
Portland State University

PDXScholar

1997

\section{Structural and Successional Analysis of Woodland Vegetation in Tualatin Hills Nature Park}

Christopher J. Dobson

Portland State University

Follow this and additional works at: https://pdxscholar.library.pdx.edu/open_access_etds

Part of the Biology Commons

Let us know how access to this document benefits you.

\section{Recommended Citation}

Dobson, Christopher J., "Structural and Successional Analysis of Woodland Vegetation in Tualatin Hills Nature Park" (1997). Dissertations and Theses. Paper 5825.

https://doi.org/10.15760/etd.7696

This Thesis is brought to you for free and open access. It has been accepted for inclusion in Dissertations and Theses by an authorized administrator of PDXScholar. Please contact us if we can make this document more accessible: pdxscholar@pdx.edu. 


\section{THESIS APPROVAL}

The abstract and thesis of Christopher J. Dobson for the Master of Science in Biology were presented June 11, 1997, and accepted by the thesis committee and the department.

COMMITTEE APPROVALS:

Dr. Robert Tinnin, Chair

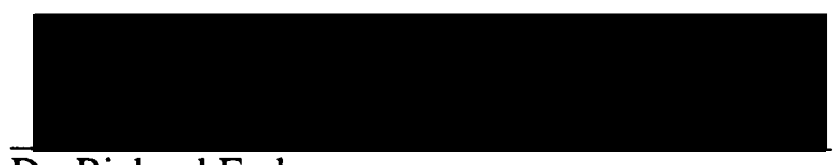

Dr. Richard Forbes

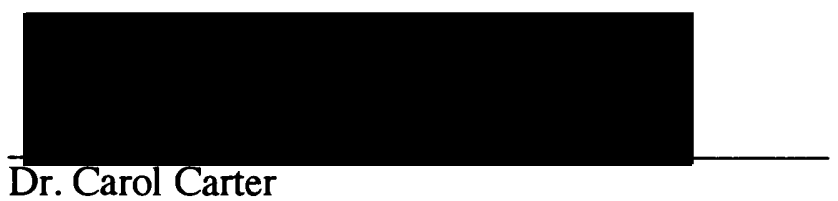

Dr. Marion Dresner

Representative of the Office of Graduate Studies

DEPARTMENTAL APPROVAL:

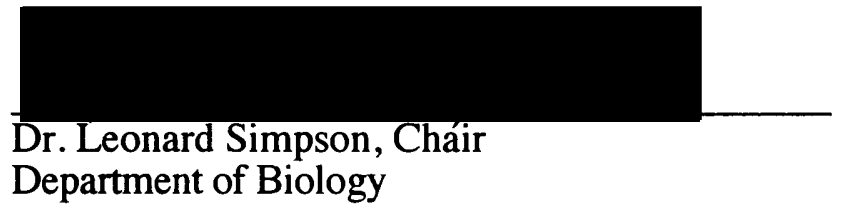

$* * * * * * * * * * * * * * * * * * * * * * * * * * * * * * * * * * * * * * * * * * * * * * * * * * * * * * * * * * * * * * * * * * * * *$

\section{ACCEPTED FOR PORTLAND STATE UNIVERSITY BY THE LIBRARY}




\begin{abstract}
An abstract of the thesis of Christopher J. Dobson for the Master of Science in Biology presented June 11, 1997.
\end{abstract}

Title: Structural and Successional Analysis of Woodland Vegetation in Tualatin Hills Nature Park.

Tualatin Hills Nature Park is an urban woodland located in Beaverton, Oregon. The park is owned and managed by Tualatin Hills Park \& Recreation District. Vegetation in the park is in a state of secondary succession following a long history of disturbance. The site provided an excellent opportunity to study the recovery of a natural woodland in an urban setting in the northern Willamette Valley.

The purpose of this study was to analyze the species composition, structure, and successional trends of the woodland vegetation in Tualatin Hills Nature Park. A secondary purpose was to determine if there were any natural grouping among the sampled plant assemblages.

Stratified random sampling was employed to collect data in eight relatively homogeneous, yet distinct plant assemblages. There were four mixed coniferous, three mixed hardwood, and one shrubland plant assemblages. $100 \mathrm{~m}^{2}$ circular plots, each containing a $10 \mathrm{~m}$ line transect, were used to collect basal area and density data of trees and frequency and cover data of trees and shrubs from mid-July to mid-October, 1995. 
Cluster analysis of basal area and cover data was used to determine if there were any natural grouping among the sampled plant assemblages. Both applications of cluster analysis grouped the mixed coniferous and mixed hardwood assemblages separately. The results of this study showed that the two types of plant assemblages were characterized by both a distinct set of tree and shrub species as well as the trees that were reproducing in the stands. This study found that the woodland vegetation in Tualatin Hills Nature Park is typical of the Willamette Valley and supports the hypothesis that under the current condition of fire suppression Abies grandis is the climax species of the Willamette Valley. 


\title{
STRUCTURAL AND SUCCESSIONAL ANALYSIS OF WOODLAND VEGETATION IN TUALATIN HILLS NATURE PARK
}

\author{
by \\ CHRISTOPHER J. DOBSON
}

A thesis submitted in partial fulfillment of the requirements for the degree of

MASTER OF SCIENCE

in

BIOLOGY

Portland State University

1997 


\section{ACKNOWLEDGEMENTS}

I am indebted to many people for their help on this project. I only hope I do not forget to thank anyone. First I would like to thank my thesis committee, Dr. Richard Forbes, Dr. Carol Carter, and Dr. Marion Dresner, for their time and efforts in improving this thesis. I especially want to thank my adviser, Dr. Robert Tinnin, who taught me scientific writing. My friends and colleagues have helped me in too many ways to mention; I would like to thank John Barbur, Kurt Carpenter, Jon Honea, Shannon Hubler, Jared May, Sherry Spencer, and Ian Waite for their contributions. I would also like to thank Raiph Cook, Elayne Barclay, and Tualatin Hilis Park \& Recreation District for their support. I would like to thank my grandfather, Raymond Joseph Karl, for help in designing field equipment. Thank you, Mother, for your eternal love and efforts as the final proofreader. My last and most heartfelt acknowledgement goes to my grandfather, Harley Harold Arrants, Sr., who taught me that if something is worth doing, it is worth doing right. Papa, you are the wisest man I have ever known. I love you. 


\section{TABLE OF CONTENTS}

\section{PAGE}

ACKNOWLEDGEMENTS ................................................ii

LIST OF TABLES....................................................... iv

LIST OF FIGURES...........................................................

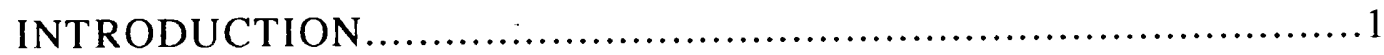

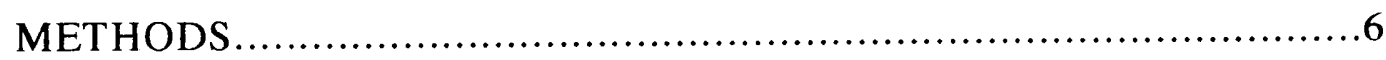

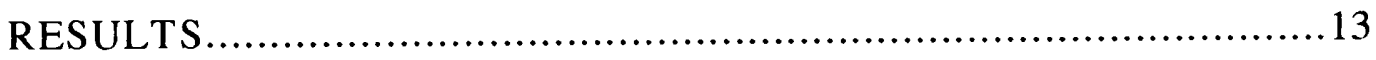

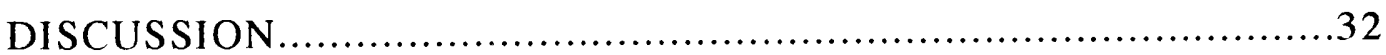

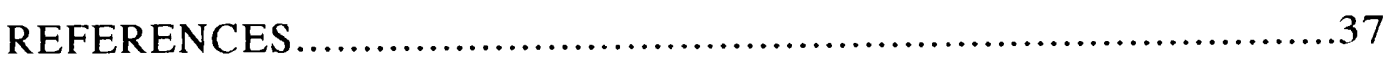

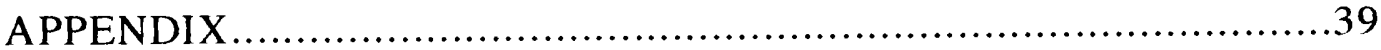




\section{LIST OFTABLES}

\section{TABLE}

PAGE

1

2

3

4

5

6

Mean basal area $\left(\mathrm{m}^{2} / \mathrm{ha}\right)$ of tree species in each plant assemblage.

Density (trees/ha) of tree species in each plant assemblage.

Frequency of occurrence in the sample of tree species in each plant assemblage.

4 Mean cover $(\mathrm{m} / 10 \mathrm{~m}$ transect) of tree species in each plant assemblage.

Frequency of shrub species in each plant assemblage

Mean cover $(\mathrm{m} / 10 \mathrm{~m}$ transect $)$ of shrub species in each plant assemblage.

Number of trees of each species ranked by diameter class in plant assemblage A (mixed coniferous).

Number of trees of each species ranked by diameter class in plant assemblage B (mixed coniferous).

Number of trees of each species ranked by diameter class in plant assemblage $\mathrm{C}$ (mixed coniferous).

Number of trees of each species ranked by diameter class in plant assemblage $D$ (mixed coniferous).

Number of trees of each species ranked by diameter class in plant assemblage $\mathrm{E}$ (mixed hardwood).

Number of trees of each species ranked by diameter class in plant assemblage $\mathrm{F}$ (mixed hardwood).

Number of trees of each species ranked by diameter class in plant assemblage $\mathrm{G}$ (mixed hardwood)

Number of trees of each species ranked by diameter class in plant assemblage $\mathrm{H}$ (shrubland). 


\section{LIST OF FIGURES}

Location of eight plant assemblages in Tualatin Hills Nature

Park.

Basal area histograph representing vertical and horizontal components of structure in a plant assemblage

Mean height and basal area of tree species by vegetative layer in plant assemblage A (mixed coniferous)

Mean height and basal area of tree species by vegetative layer in plant assemblage B (mixed coniferous).

Mean height and basal area of tree species by vegetative layer in plant assemblage C (mixed coniferous)

Mean height and basal area of tree species by vegetative layer in plant assemblage $\mathrm{D}$ (mixed coniferous)

Mean height and basal area of tree species by vegetative layer in plant assemblage $E$ (mixed hardwood).

$8 \quad$ Mean height and basal area of tree species by vegetative layer in plant assemblage $F$ (mixed hardwood)

9 Mean height and basal area of tree species by vegetative layer in plant assemblage $\mathrm{G}$ (mixed hardwood).................25

10 Mean height and basal area of tree species by vegetative layer in plant assemblage $\mathrm{H}$ (shrubland).

11 Dendrogram from the cluster analysis of eight plant assemblages, based on tree basal area data

12 Dendrogram from the cluster analysis of eight plant assemblages, based on tree and shrub cover data 


\section{INTRODUCTION}

The greater Portland area comprises many natural areas. Some of these areas more closely approach a natural state than others. One such area is Tualatin Hills Nature Park, which is located in Beaverton, Oregon, within the Willamette Valley Province of Oregon (Franklin and Dyrness 1973). The woodland vegetation in Tualatin Hills Nature Park is in a state of recovery from the following known disturbances: clearing, logging, grazing, farming, fire, stream channeling, and recreational use. Much of the historical evidence for these disturbances is outlined by McKinstry (1983). There may well have been other causes of disturbance in the past. Whatever the exact combination of disturbances may have been, today one observes an 80-acre parcel that contains a mosaic of vegetation types. This mosaic may reflect the site's disturbance history, an underlying variation in edaphic factors, an interplay of chance events, or some combination of these factors. Tualatin Hills Nature Park provides an excellent opportunity to examine woodland recovery in an urban setting. What is learned from this study will contribute to more informed park management of natural woodlands in the northern Willamette Valley.

\section{Vegetation in the Willamette Valley}

Habeck (1961) and Johannessen et al. (1971) developed a description of the original vegetation of the Willamette Valley using land survey records from the mid1850s and early historical accounts of explorers and pioneers. The majority of the presettlement Willamette Valley was occupied by prairies and oak savannas, the principal tree species being Quercus garryana (Oregon white oak). Occasional associates 
included Pinus ponderosa (ponderosa pine) and Pseudotsuga menziesii (Douglas-fir) (Habeck 1961).

The open prairies and oak savannas were maintained by fires set primarily by the Kalapuya Indians, aboriginal inhabitants of the Willamette Valley (Habeck 1961, Johannessen et al. 1971). The fires were set annually in the late summer or early fall to improve food gathering and hunting. Several researchers (Habeck 1961, Thilenius 1968, Johannessen et al. 1971, Towle 1974) have concluded that the prairies and oak savannas of the pre-settlement Willamette Valley were seral communities, maintained by regular burning.

Pre-settlement vegetation of the Willamette Valley also included Douglas-fir forests, riparian forests, and closed-canopy oak forests (Habeck 1961, Johannessen et al. 1971). Habeck (1961) concluded that the occasional closed-canopy oak forests occurred in sites protected from fire and that the Douglas-fir forests were restricted by fire to the foothills along the periphery of the Valley. Predominant tree species in the pre-settlement vegetation included Acer macrophyllum (bigleaf maple), Cornus nuttallii (Pacific dogwood), Fraxinus latifolia (Oregon ash), Populus trichocarpa (black cottonwood), Pseudotsuga menziesii, Quercus garryana, Thuja plicata (western redcedar), and Tsuga heterophylla (western hemlock) in various proportions from site to site (Habeck 1961, Johannessen et al. 1971).

\section{Post-European Settlement Vegetation in the Willamette Valley}

Since European settlement in the early-to-mid-1800s, vegetation in the Willamette Valley has been affected by such human activities as fire prevention, clearing, logging, grazing, and urban development. Due to the severity and 
ubiquitous nature of European influence, vegetation in the Willamette Valley continues to exist in a highly modified state (Franklin and Dyrness 1973).

Habeck (1961) concluded that very little of the pre-European Willamette Valley vegetation remains. A major change in the vegetation has been the replacement of prairies and oak savannas by closed-canopy oak forests, as a result of fire suppression (Habeck 1961, Thilenius 1968). Evidence of this process is apparent in the two-aged stands of Quercus garryana, which are common in the Willamette Valley (Franklin and Dyrness 1973). They consist of scattered, open-grown oaks surrounded by closed stands of closely spaced, smaller oaks. Current woodlands in the Willamette Valley are typically dominated by Quercus garryana, associated with Abies grandis (grand fir), Acer macrophyllum, and Pseudotsuga menziesii (Thilenius 1968).

The coniferous forests that occupy the foothills in and around the periphery of the Willamette Valley are dominated by Pseudotsuga menziesii (Franklin and Dyrness 1973) associated with Abies grandis, Acer macrophyllum, Quercus garryana, Thuja plicata, and Tsuga heterophylla. Franklin and Dyrness (1973) noted that Pinus ponderosa is often an associate in specialized habitats, such as alluvial deposits subject to high water tables in winter and drought in summer.

Riparian forests in the Willamette Valley predominantly consist of hardwood species such as Fraxinus latifolia, Populous trichocarpa, and Salix spp. (willow spp.) associated with Acer macrophyllum, Alnus rubra (red alder), Pinus ponderosa, and Quercus garryana (Franklin and Dyrness 1973).

\section{Succession in the Willamette Valley}

In the Willamette Valley, hardwoods function as pioneers to conifers in succession, producing various hardwood-conifer mixtures (Franklin and Dyrness 
1973). Sprague and Hansen (1946) found previously non-forested areas in the midWillamette Valley being invaded by Quercus garryana, followed by Pseudotsuga menziesii and then Abies grandis. The authors suggested a successional progression from Quercus garryana to Pseudotsuga menziesii to Abies grandis, or possibly both Abies grandis and Pseudotsuga men-iesii.

After reconstructing the pre-settlement vegetation in the southern Willamette Valley, Towle (1982) concluded that the foothills had been transformed from open woodland to closed forest. The transformation included Pseudotsuga menziesii replacing Quercus garryana as the predominant species. Towle (1982) attributed this transformation to the ability of Pseudotsuga menziesii to germinate and survive under the Quercus garryana canopy and its ability to outgrow and eventually shade out the Quercus garryana.

Cole (1977) found a difference in successional trends between mesic and xeric sites in foothills of the southern Willamette Valley. On mesic sites, forests of Pseudotsugamenziesii were being replaced by Abies grandis, Acer macrophyllum, and Cornusnuttallii. Relatively xeric sites supported a more open forest of Pinus ponderosa and Quercus garryana associated with Pseudotsuga menziesii. Although there were Pseudotsuga menziesii seedlings on the relatively xeric sites, Abies grandis was invading, and Cole (1977) concluded that the species would eventually dominate the xeric sites as well.

Franklin and Dyrness (1973) concluded that there are several potential climax communities in the Willamette Valley, depending on the particular habitat, but that the most likely climax would be dominated by Abies grandis. The authors diagrammed possible successional sequences passing through stands composed of various mixtures of Abies grandis, Acer macrophyllum, Pseudotsuga menziesii, and Quercus 
garryana. In all scenarios Franklin and Dyrness (1973) concluded that the climax vegetation in the Willamette Valley is coniferous forest, dominated by Abies grandis. Tualatin Hills Nature Park provided an opportunity to evaluate successional patterns in the northern Willamette Valley. This study was designed to characterize the species composition and structure of woodland vegetation in the park and to estimate patterns of vegetative change. A secondary purpose was to determine if there were any natural grouping of the sampled plant assemblages, based on similarities in species composition, structure, and successional trends. 


\section{METHODS}

\section{Site Description}

The 80-hectare Tualatin Hills Nature Park is located along S.W. 170th Avenue, south of Merlo Drive and north of Tualatin Valley Highway (State Highway 8) in Beaverton, Washington County, Oregon (N.E. 1/4 section 7, N.W. 1/4 section 8, T1S, R1W). The park is within the Tualatin River Watershed and comprises nearly level terraces and floodplains (Jones \& Jones: Architects \& Landscape Architects 1984) adjacent to the confluence of Cedar Mill Creek and Beaverton Creek. Surface elevations range from 49-58 $\mathrm{m}$ above sea level. The soils underlying the park are typical of those found in the Willamette Valley and were formed from deep silty or clayey alluvium and lacustrine material (Jones \& Jones: Architects \& Landscape Architects 1984). The woodland vegetation studied included mixed coniferous, mixed hardwood, and shrubland plant assemblages in what appeared to be different stages of secondary succession.

\section{Sampling Method}

Eight relatively homogeneous plant assemblages in the park were designated for sampling (Figure 1). Of these eight assemblages, four were mixed coniferous, three were mixed hardwood, and one was shrubland. The plant assemblages were delineated based on differences in physiognomy. Conifers comprised the overstory in the mixed coniferous stands, and hardwoods comprised the overstory in the mixed hardwood stands. Stratified random sampling was used to identify the location of sample units (100 $\mathrm{m}^{2}$ circular plots) within each of the eight assemblages. One mixed coniferous assemblage contained 15 sample units, while the other seven assemblages each 
Figure 1. Location of eight plant assemblages in Tualatin Hills Nature Park.

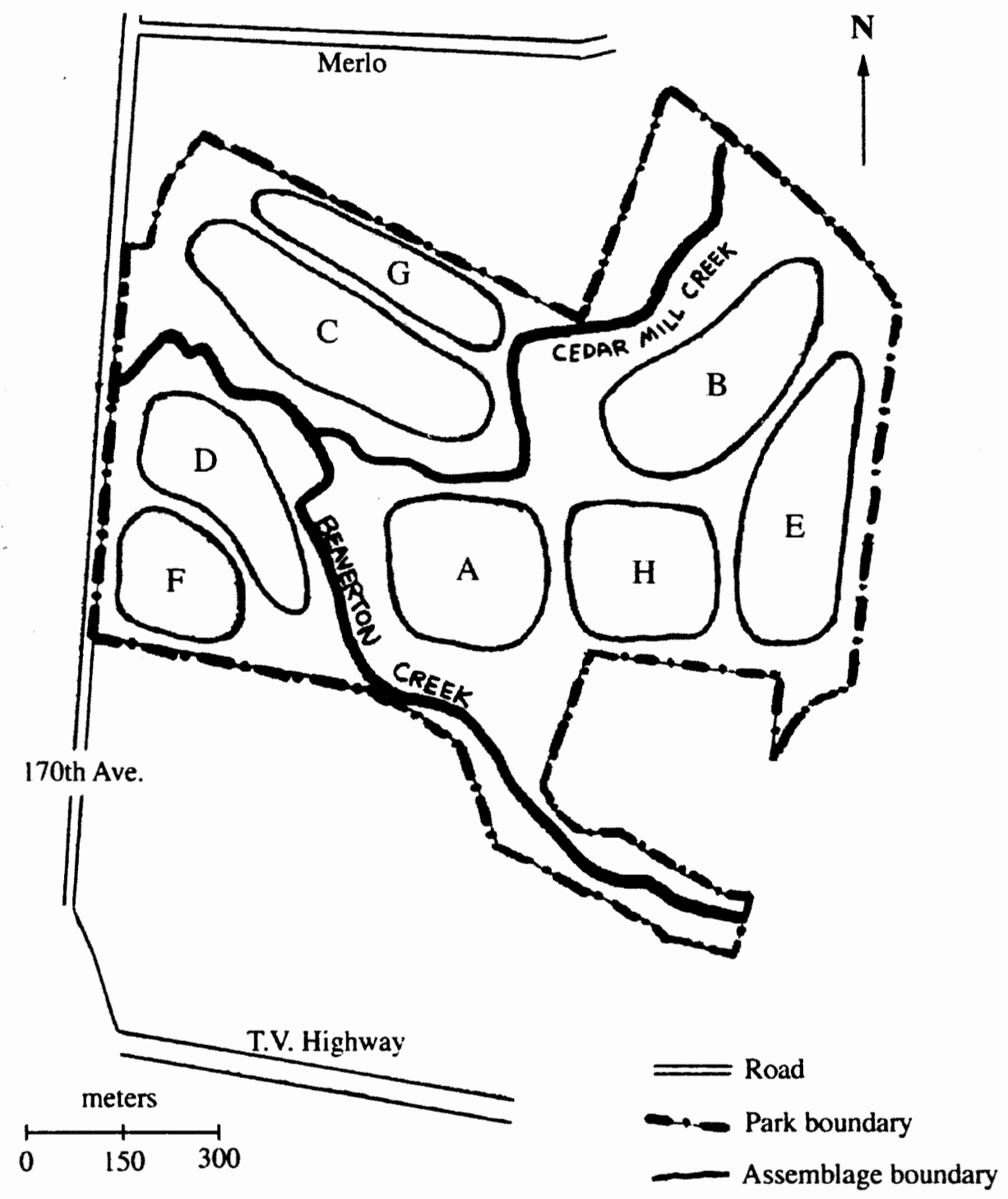


contained 10 sample units, for a total of 85 sample units. Each sample unit was located in the field using a numbered grid superimposed over an aerial photograph of the park.' Reference trees were identified on the photograph and subsequently located on the ground within the park. Each sample unit was located from these trees, and a $100 \mathrm{~m}^{2}$ circular plot was established by driving three wooden stakes into the ground along a line running east to west across the center of the plot. One stake was positioned in the center of the plot and the other two at east and west boundaries. Plot boundaries were $5.64 \mathrm{~m}$ from the center stake. A $10 \mathrm{~m}$ line transect was established and centered along the eastwest diameter of each plot at approximately $1 \mathrm{~m}$ above ground level.

The circular plots were used to measure basal area and density of trees and frequency of trees and shrubs. The $10 \mathrm{~m}$ transects were used to measure cover of trees and shrubs. Herbaceous plants were not sampled because their presence was transient over the course of the study. All species nomenclature follows Hitchcock and Cronquist (1973)..$^{2}$ Tree species were defined as usually single-stemmed, woody plants $>10 \mathrm{~m}$ in height when mature, and shrub species as multi-stemmed, woody plants $<10 \mathrm{~m}$ in height when mature (Pojar and MacKinnon 1994).

Green (1982) showed several soil types in the park. One $0.5 \mathrm{~m}$ deep soil pit was dug in each plant assemblage to confirm Green's designation. Each pit was located near the center of each plant assemblage.

'The photograph was taken in 1992 and provided by Kurahashi \& Associates: Landscape Architects.

2 A species list of sampled trees and shrubs, with scientific and common names, is presented in the Appendix. 


\section{Data Collection}

Data collection occurred from mid-July to mid-October, 1995. Tree diameters at breast height $(\mathrm{dbh})$ were measured to the nearest $0.5 \mathrm{~cm}$ with a diameter tape at $1.4 \mathrm{~m}$ above ground level (Bonham 1989) for all trees with a dbh $\geq 2 \mathrm{~cm}$. A tree was considered to be in a plot if the center of its bole at ground level was within the plot boundary. The dbh of each stem was measured for trees whose boles were divided into more than one stem at breast height.

The number of individuals of each tree species was determined in each plot for plants having a dbh $\geq 2 \mathrm{~cm}$. Plants with multiple stems were counted only once. The height of each plant counted was measured directly, or for plants $>5 \mathrm{~m}$ in height a clinometer was used (Bonham 1989).

The cover $(\mathrm{m} / 10 \mathrm{~m}$ transect $)$ of each tree and shrub species in a plant assemblage was measured by the line-intercept method (Bonham 1989). This was accomplished by measuring the interception of the foliage of each tree and shrub species with the vertical plane defined by the $10 \mathrm{~m}$ transect in each plot.

\section{Data Evaluation}

To represent horizontal and vertical components of structure in each plant assemblage, mean basal area $\left(\mathrm{m}^{2} / \mathrm{ha}\right)$ for each tree species was calculated from $\mathrm{dbh}$ measurements (Bonham 1989). For a multi-stemmed tree, the basal area of each stem was calculated, and these values were summed to determine the basal area of the tree. The arboreal vegetation was grouped into each of three arbitrarily established layers. The understory layer contained plants $<10 \mathrm{~m}$ in height. The lower canopy layer 
contained plants $\geq 10 \mathrm{~m}$ in height, but $<20 \mathrm{~m}$ in height. The overstory layer contained plants $\geq 20 \mathrm{~m}$ in height. The resulting data were then plotted in a two-dimensional figure, which I have named a basal area histograph. Figure 2 illustrates the basic form of each basal area histograph. The heights and widths of each rectangle illustrate the mean height and mean basal area, respectively, of each tree species within a given height layer.

A diameter class distribution of tree species in each sample was determined by placing individuals of each species into one of 11 diameter classes (Tables 7-14). The classes were $<2 \mathrm{~cm} \mathrm{dbh} ; \geq 2 \mathrm{~cm}$, but $<5 \mathrm{~cm} \mathrm{dbh;} \geq 5 \mathrm{~cm}$, but $<10 \mathrm{~cm} \mathrm{dbh;} \mathrm{and}$ then decade increments from $\geq 10 \mathrm{~cm}$ to $\geq 80 \mathrm{~cm} \mathrm{dbh}$.

Cluster analysis was applied to both the basal area and cover data of each sample, and dendrograms were constructed to illustrate the similarity between each plant assemblage. Cophenetic correlation coefficients were calculated to measure data distortion, where coefficients greater than 0.8 would indicate minimal distortion (Romesburg 1984). A Q-mode analysis (measuring the similarity of independent samples) of attributes of each plant assemblage was performed in two applications: the first measured the similarity of each plant assemblage based on tree basal area data; the second measured the similarity of each plant assemblage based on tree and shrub cover data.

Chord distance was used as the resemblance coefficient because it is expressed on a standardized scale (Ludwig and Reynolds 1988). This procedure emphasizes the relative proportions rather than absolute quantities of object attributes in a cluster analysis. Ludwig and Reynolds (1988) recommended the use of chord distance because they found it to perform well on data from a wide range of ecological circumstances. 


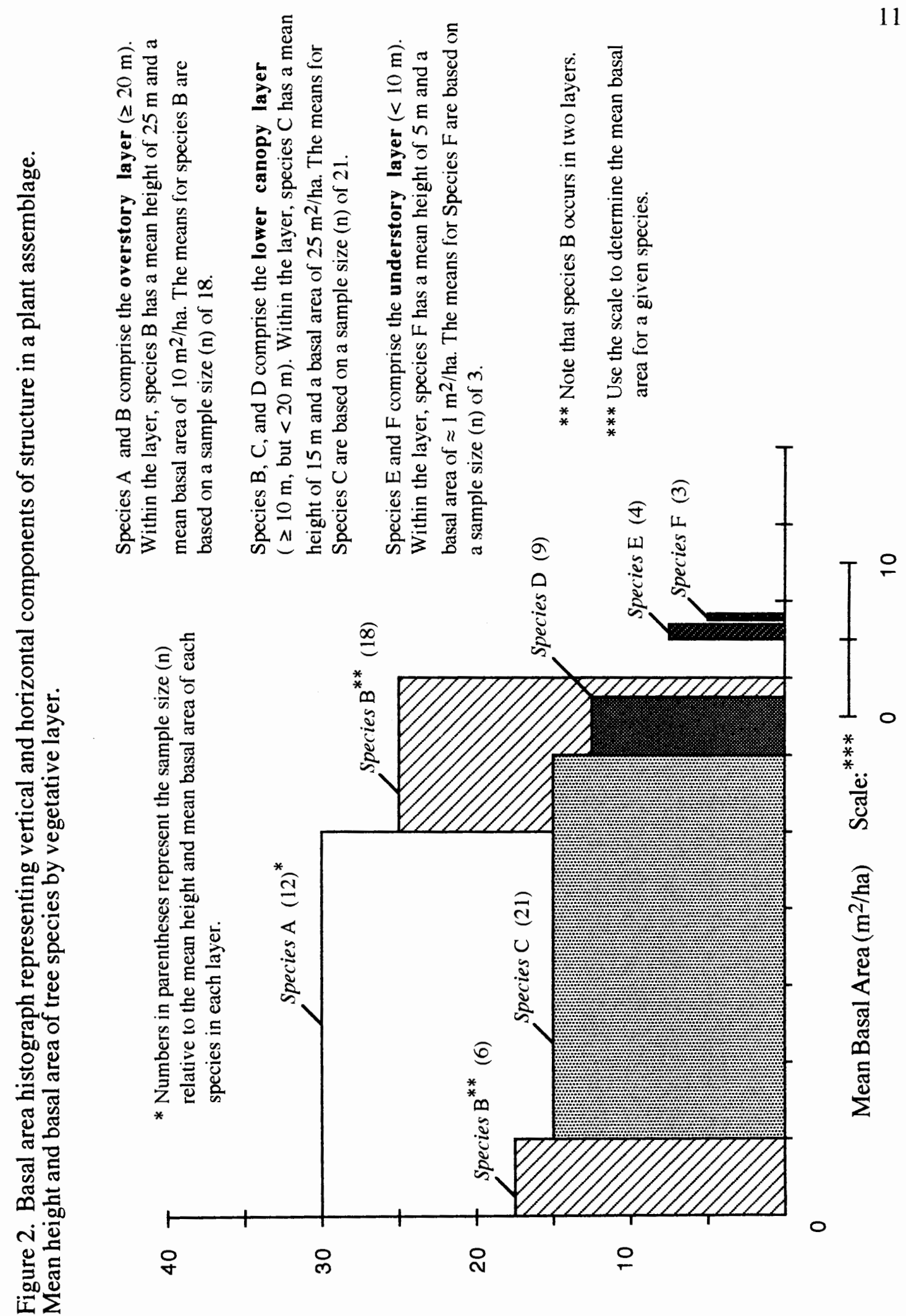

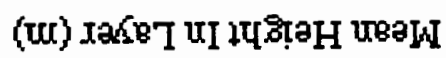


The UPGMA (unweighted pair-group method using arithmetic averages) clustering method was used, as recommended by Romesburg (1984), because it produces less distortion than similar methods in transforming the data into dendrograms. SYN-TAX Computer Programs for Multivariate Data Analysis in Ecology and Systematics (Podani 1993) was used for all analyses. 


\section{RESULTS}

The four mixed coniferous plant assemblages (A, B, C, and D) were similar in species composition and structure. Although species composition included both coniferous and hardwood tree species, conifers made the predominant contributions to community structure. Tree species with a relatively large mean basal area, density, frequency, and mean cover included Abies grandis, Acer macrophyllum, Alnus rubra, Pseudotsuga menziesii, Thuja plicata, and Tsuga heterophylla (Tables 1-4). Shrubs also helped to distinguish the mixed coniferous plant assemblages. Acer circinatum (vine maple), Berberis nervosa (dwarf Oregon-grape), and Sambucus racemosa (red elderberry) had a comparatively large frequency and mean cover in the mixed coniferous plant assemblages (Tables 5 and 6).

Table 1. Mean basal area $\left(\mathrm{m}^{2} / \mathrm{ha}\right)$ of tree species in each plant assemblage.

\begin{tabular}{lcccccccc} 
& \multicolumn{4}{c}{ Mixed Coniferous } & \multicolumn{3}{c}{ Mixed Hardwood } & Shrubland \\
\multicolumn{1}{c}{ Tree Species } & A & B & C & D & E & F & G & H \\
Abies grandis & 0.12 & 8.61 & 4.80 & 5.88 & 1.40 & 0.03 & 0.30 & 0.33 \\
Acer macrophyllum & 6.42 & 0.00 & 4.88 & 0.35 & 0.59 & 0.00 & 0.34 & 2.57 \\
Alnus rubra & 0.00 & 0.00 & 6.97 & 9.20 & 0.00 & 0.00 & 0.00 & 0.00 \\
Betula sp. & 0.00 & 0.00 & 0.03 & 0.00 & 0.00 & 0.00 & 0.00 & 0.00 \\
Cornus nuttallii & 0.95 & 0.00 & 0.03 & 0.00 & 0.45 & 0.00 & 0.00 & 0.85 \\
Fraxinus latifolia & 0.00 & 0.00 & 0.10 & 0.00 & 1.56 & 15.27 & 6.93 & 0.02 \\
Pinus ponderosa & 0.00 & 0.00 & 0.00 & 0.00 & 2.24 & 4.24 & 1.02 & 0.80 \\
Prunus sp. & 0.00 & 0.00 & 0.00 & 0.00 & 0.00 & 0.00 & 0.12 & 0.00 \\
Prunus emarginata & 0.00 & 0.00 & 0.00 & 0.00 & 0.10 & 0.00 & 0.00 & 0.02 \\
Pseudotsuga menziesii & 41.63 & 45.80 & 30.76 & 15.00 & 7.07 & 2.14 & 4.44 & 0.50 \\
Quercus garryana & 0.00 & 0.00 & $\mathbf{2 . 4 5}$ & 0.00 & 19.76 & 13.48 & 20.74 & 2.92 \\
Taxus brevifolia & 0.15 & 0.00 & 0.00 & 0.00 & 0.00 & 0.00 & 0.00 & 0.50 \\
Thuja plicata & 0.41 & 2.21 & 0.33 & $\mathbf{2 2 . 9 7}$ & 0.00 & 0.00 & 0.00 & 2.06 \\
Tsuga heterophylla & $\underline{0.22}$ & $\underline{0.00}$ & $\underline{0.00}$ & $\underline{1.92}$ & $\underline{0.00}$ & $\underline{0.00}$ & $\underline{0.00}$ & $\underline{0.00}$ \\
\multicolumn{1}{c}{ Total } & 49.90 & $\mathbf{5 6 . 6 2}$ & $\mathbf{5 0 . 3 5}$ & $\mathbf{5 5 . 3 1}$ & $\mathbf{3 3 . 1 6}$ & $\mathbf{3 5 . 1 7}$ & $\mathbf{3 3 . 8 8}$ & 10.58
\end{tabular}


Table 2. Density (trees/ha) of tree species in each plant assemblage.

\begin{tabular}{lcccccccc} 
& \multicolumn{4}{c}{ Mixed Coniferous } & \multicolumn{3}{c}{ Mixed Hardwood } & Shrubland \\
\multicolumn{1}{c}{ Tree species } & A & B & C & D & E & F & G & H \\
Abies grandis & 27 & 70 & 50 & 40 & 50 & 30 & 50 & 80 \\
Acer macrophyllum & 213 & 0 & 40 & 10 & 20 & 10 & 10 & 10 \\
Alnus rubra & 0 & 0 & 190 & 50 & 0 & 0 & 0 & 0 \\
Betula sp. & 0 & 0 & 10 & 0 & 0 & 0 & 0 & 0 \\
Cornus nuttallii & 40 & 0 & 10 & 0 & 50 & 0 & 0 & 90 \\
Fraxinus latifolia & 0 & 0 & 10 & 0 & 60 & 370 & 290 & 20 \\
Pinus ponderosa & 0 & 0 & 0 & 0 & 10 & 10 & 10 & 40 \\
Prunus sp. & 0 & 0 & 0 & 0 & 0 & 0 & 20 & 0 \\
Prunus emarginata & 0 & 0 & 0 & 0 & 10 & 0 & 0 & 10 \\
Pseudotsuga menziesii & 227 & 200 & 160 & 60 & 150 & 30 & 50 & 40 \\
Quercus garryana & 0 & 0 & 20 & 0 & 450 & 180 & 140 & 50 \\
Taxus brevifolia & 7 & 0 & 0 & 0 & 0 & 0 & 0 & 30 \\
Thuja plicata & 20 & 10 & 20 & 210 & 0 & 0 & 0 & 40 \\
Tsuga heterophylla & 7 & 0 & 0 & 60 & 0 & 0 & 0 & 0
\end{tabular}

Table 3. Frequency of occurrence in the sample of tree species in each plant assemblage.

\begin{tabular}{lcccccccc} 
& \multicolumn{4}{c}{ Mixed Coniferous } & \multicolumn{2}{c}{ Mixed Hardwood } & Shrubland \\
\multicolumn{1}{c}{ Tree Species } & A & B & C & D & E & F & G & H \\
Abies grandis & 0.20 & 0.60 & 0.20 & 0.40 & 0.50 & 0.40 & 0.40 & 0.60 \\
Acer macrophyllum & 0.67 & 0.10 & 0.20 & 0.30 & 0.10 & 0.10 & 0.20 & 0.10 \\
Alnus rubra & 0.00 & 0.00 & 0.50 & 0.50 & 0.00 & 0.00 & 0.00 & 0.00 \\
Betula sp. & 0.00 & 0.00 & 0.10 & 0.00 & 0.00 & 0.00 & 0.00 & 0.00 \\
Cornus nuttallii & 0.27 & 0.00 & 0.10 & 0.00 & 0.10 & 0.00 & 0.00 & 0.50 \\
Fraxinus latifolia & 0.00 & 0.10 & 0.10 & 0.00 & 0.70 & 0.90 & 0.80 & 0.30 \\
Pinus ponderosa & 0.00 & 0.00 & 0.00 & 0.00 & 0.10 & 0.10 & 0.10 & 0.10 \\
Prunus sp. & 0.00 & 0.00 & 0.00 & 0.00 & 0.00 & 0.00 & 0.10 & 0.00 \\
Prunus emarginata & 0.00 & 0.00 & 0.00 & 0.00 & 0.10 & 0.00 & 0.00 & 0.10 \\
Pseudotsuga menziesii & 0.80 & 0.90 & 0.80 & 0.50 & 0.80 & 0.20 & 0.40 & 0.30 \\
Quercus garryana & 0.00 & 0.00 & 0.10 & 0.00 & 0.70 & 0.60 & 0.70 & 0.20 \\
Taxus brevifolia & 0.07 & 0.00 & 0.00 & 0.00 & 0.00 & 0.00 & 0.00 & 0.20 \\
Thuja plicata & 0.20 & 0.10 & 0.10 & 0.90 & 0.00 & 0.00 & 0.00 & 0.10 \\
Tsuga heterophylla & 0.07 & 0.00 & 0.00 & 0.50 & 0.00 & 0.00 & 0.00 & 0.00
\end{tabular}


Table 4. Mean cover $(\mathrm{m} / 10 \mathrm{~m}$ transect) of tree species in each plant assemblage.

\begin{tabular}{lcccccccc} 
& \multicolumn{4}{c}{ Mixed Coniferous } & \multicolumn{3}{c}{ Mixed Hardwood } & Shrubland \\
\multicolumn{1}{c}{ Tree Species } & A & B & C & D & E & F & G & H \\
Abies grandis & 0.2 & 0.9 & 1.3 & 1.5 & 0.1 & 0.0 & 0.2 & 0.6 \\
Acer macrophyllum & 6.0 & 0.0 & 1.5 & 0.5 & 0.6 & 0.0 & 0.1 & 0.9 \\
Alnus rubra & 0.0 & 0.0 & 2.1 & 1.9 & 0.0 & 0.0 & 0.0 & 0.0 \\
Cormus nuttallii & 1.4 & 0.0 & 0.3 & 0.0 & 0.7 & 0.0 & 0.0 & 0.6 \\
Fraxinus latifolia & 0.0 & 0.0 & 0.1 & 0.0 & 1.2 & 6.2 & 4.8 & 0.1 \\
Pinus ponderosa & 0.0 & 0.0 & 0.0 & 0.0 & 0.0 & 0.5 & 0.0 & 0.3 \\
Prunus sp. & 0.0 & 0.0 & 0.0 & 0.0 & 0.0 & 0.0 & 0.2 & 0.0 \\
Pseudotsuga mentiesii & 7.4 & 8.5 & 4.9 & 3.6 & 4.7 & 0.5 & 1.1 & 0.6 \\
Quercus garryana & 0.0 & 0.0 & 0.5 & 0.0 & 6.1 & 3.7 & 4.3 & 0.5 \\
Taxus brevifolia & 0.3 & 0.0 & 0.0 & 0.1 & 0.0 & 0.0 & 0.0 & 0.2 \\
Thuja plicata & 0.2 & 0.7 & 0.7 & 5.2 & 0.0 & 0.0 & 0.0 & 0.0 \\
Tsuga heterophylla & $\underline{0.0}$ & $\underline{0.0}$ & $\underline{0.0}$ & $\underline{1.5}$ & $\underline{0.0}$ & $\underline{0.0}$ & $\underline{0.0}$ & $\underline{0.0}$ \\
\multicolumn{1}{c}{ Total } & 15.3 & $\mathbf{1 0 . 1}$ & $\mathbf{1 1 . 1}$ & $\mathbf{1 4 . 2}$ & $\mathbf{1 3 . 3}$ & $\mathbf{1 0 . 9}$ & 10.6 & 3.7
\end{tabular}

Although the mixed hardwood plant assemblages (E, F, and G) also included coniferous tree species, hardwoods defined community structure. Fraxinus latifolia and Quercus garryana had a relatively large mean basal area, density, frequency, and mean cover (Tables 1-4). The shrub species that helped distinguish the mixed hardwood plant assemblages were Amelanchier alnifolia (serviceberry), Rhamnus purshiana (cascara), and Symphoricarpos albus (snowberry) (Tables 5 and 6).

Shrubs dominated the shrubland plant assemblage $(\mathrm{H})$. The shrubland had the smallest total basal area and cover of trees (Tables 1 and 4) and the largest total cover of shrubs (Table 6) of the eight plant assemblages. Shrubs with a comparatively large frequency and mean cover included Acer circinatum, Corylus cornuta var. californica (California hazel), Gaultheria shallon (salal), Holodiscus discolor (ocean spray), and Rhamnus purshiana (Table 6). 
Table 5. Frequency of shrub species in each plant assemblage.

\begin{tabular}{|c|c|c|c|c|c|c|c|c|}
\hline \multirow[b]{2}{*}{ Shrub Species } & \multicolumn{4}{|c|}{ Mixed Coniferous } & \multicolumn{3}{|c|}{ Mixed Hardwood } & \multirow{2}{*}{$\begin{array}{c}\text { Shrubland } \\
\text { H }\end{array}$} \\
\hline & $\mathbf{A}$ & $\mathbf{B}$ & $\mathrm{C}$ & D & $\mathbf{E}$ & $\mathbf{F}$ & G & \\
\hline Acer circinatum & 0.67 & 1.00 & 1.00 & 0.80 & 0.10 & 0.10 & 0.30 & 0.80 \\
\hline Amelanchier alnifolia & 0.00 & 0.10 & 0.10 & 0.00 & 0.80 & 0.80 & 0.60 & 0.30 \\
\hline Berberis aquilfolium & 0.20 & 0.20 & 0.10 & 0.10 & 0.60 & 0.10 & 0.40 & 0.70 \\
\hline Berberis nervosa & 0.67 & 1.00 & 0.70 & 0.50 & 0.00 & 0.00 & 0.10 & 0.00 \\
\hline Corylus cornuta & 0.67 & 0.80 & 0.80 & 0.40 & 1.00 & 0.60 & 1.00 & 1.00 \\
\hline Cornus stolonifera & 0.13 & 0.00 & 0.00 & 0.00 & 0.10 & 0.10 & 0.30 & 0.00 \\
\hline Crataegus douglasii & 0.00 & 0.00 & 0.00 & 0.00 & 0.00 & 0.00 & 0.00 & 0.10 \\
\hline Crataegus monogyna & 0.13 & 0.00 & 0.00 & 0.00 & 0.00 & 0.60 & 0.10 & 0.10 \\
\hline Gaultheria shallon & 0.20 & 0.90 & 0.70 & 0.20 & 0.40 & 0.10 & 0.80 & 1.00 \\
\hline Hedera helix & 0.07 & 0.10 & 0.20 & 0.10 & 0.00 & 0.20 & 0.00 & 0.00 \\
\hline Holodiscus discolor & 0.07 & 0.30 & 0.30 & 0.00 & 0.50 & 0.00 & 0.60 & 1.00 \\
\hline Ilex aquilfolium & 0.07 & 0.50 & 0.00 & 0.60 & 0.10 & 0.10 & 0.00 & 0.10 \\
\hline Lonicera sp. & 0.07 & 0.00 & 0.10 & 0.00 & 0.70 & 0.40 & 0.00 & 0.00 \\
\hline Oemleria cerasiformis & 0.20 & 0.60 & 0.00 & 0.30 & 0.20 & 0.40 & 0.00 & 0.10 \\
\hline Physocarpus capilatus & 0.00 & 0.20 & 0.40 & 0.00 & 0.00 & 0.00 & 0.20 & 0.00 \\
\hline Rhamnus purshiana & 0.20 & 0.50 & 0.50 & 0.60 & 1.00 & 0.80 & 1.00 & 1.00 \\
\hline Rhus diversiloba & 0.00 & 0.00 & 0.00 & 0.00 & 0.80 & 0.20 & 0.10 & 0.60 \\
\hline Ribes lacustre & 0.07 & 0.00 & 0.00 & 0.00 & 0.00 & 0.00 & 0.00 & 0.00 \\
\hline Rosa gymnocarpa & 0.07 & 0.20 & 0.20 & 0.00 & 0.30 & 0.30 & 0.00 & 0.40 \\
\hline Rosa nutkana & 0.00 & 0.00 & 0.00 & 0.00 & 0.00 & 0.40 & 0.00 & 0.00 \\
\hline Rosa pisocarpa & 0.00 & 0.00 & 0.00 & 0.00 & 0.10 & 0.00 & 0.40 & 0.10 \\
\hline Rosa sp. & 0.00 & 0.00 & 0.00 & 0.00 & 0.00 & 0.00 & 0.10 & 0.00 \\
\hline Rubus discolor & 0.00 & 0.00 & 0.00 & 0.00 & 0.00 & 0.40 & 0.00 & 0.20 \\
\hline Rubus parviflorus & 0.20 & 0.00 & 0.60 & 0.00 & 0.00 & 0.00 & 1.00 & 0.50 \\
\hline Rubus ursinus & 1.00 & 1.00 & 0.90 & 1.00 & 1.00 & 1.00 & 1.00 & 1.00 \\
\hline Sambucus racemosa & 0.80 & 0.80 & 0.80 & 0.50 & 0.00 & 0.00 & 0.00 & 0.00 \\
\hline Spiraea douglasii & 0.00 & 0.00 & 0.00 & 0.00 & 0.00 & 0.00 & 0.30 & 0.00 \\
\hline Symphoricarpos albus & 0.73 & 0.60 & 0.60 & 0.50 & 1.00 & 1.00 & 1.00 & 0.80 \\
\hline Vaccinium parvifolium & 0.40 & 0.00 & 0.00 & 0.20 & 0.00 & 0.00 & 0.00 & 0.60 \\
\hline
\end{tabular}


Table 6. Mean cover $(\mathrm{m} / 10 \mathrm{~m}$ transect $)$ of shrub species in each plant assemblage.

\begin{tabular}{lcccccccc} 
& \multicolumn{3}{c}{ Mixed Coniferous } & \multicolumn{4}{c}{ Mixed Hardwood } & Shrubland \\
\multicolumn{1}{c}{ Shrub Species } & A & B & C & D & E & F & G & H \\
Acer circinatum & 3.1 & 5.2 & 3.5 & 0.7 & 0.0 & 0.0 & 0.0 & 2.1 \\
Amelanchier alnifolia & 0.0 & 0.0 & 0.0 & 0.0 & 3.3 & 2.1 & 0.5 & 0.3 \\
Berberis aquilfolium & 0.0 & 0.0 & 0.0 & 0.0 & 0.0 & 0.0 & 0.0 & 0.1 \\
Berheris nervosa & 0.7 & 3.0 & 0.2 & 0.1 & 0.0 & 0.0 & 0.0 & 0.0 \\
Corylus cornuta & 2.0 & 1.1 & 2.0 & 0.4 & 2.6 & 0.9 & 1.7 & 6.0 \\
Cornus stolonifera & 0.0 & 0.0 & 0.0 & 0.0 & 0.0 & 0.0 & 0.5 & 0.0 \\
Crataegus monogyna & 0.1 & 0.0 & 0.0 & 0.0 & 0.0 & 0.3 & 0.0 & 0.0 \\
Gaultheria shallon & 0.0 & 0.8 & 1.0 & 0.0 & 0.4 & 0.3 & 1.7 & 3.6 \\
Hedera helix & 0.0 & 0.0 & 0.1 & 0.0 & 0.0 & 0.0 & 0.0 & 0.0 \\
Holodiscus discolor & 0.0 & 0.0 & 0.0 & 0.0 & 0.1 & 0.0 & 0.5 & 1.0 \\
Oemleria cerasiformis & 0.0 & 0.1 & 0.0 & 0.1 & 0.0 & 0.0 & 0.0 & 0.0 \\
Physocarpus capitatus & 0.0 & 0.0 & 0.2 & 0.0 & 0.0 & 0.0 & 0.1 & 0.0 \\
Rhamnus purshiana & 0.0 & 0.0 & 0.2 & 0.0 & 0.8 & 0.3 & 2.2 & 4.0 \\
Rhus diversiloba & 0.0 & 0.0 & 0.0 & 0.0 & 0.4 & 0.2 & 0.0 & 0.0 \\
Rosa gymnocarpa & 0.0 & 0.0 & 0.1 & 0.0 & 0.0 & 0.0 & 0.0 & 0.0 \\
Rosa mutkana & 0.0 & 0.0 & 0.0 & 0.0 & 0.0 & 0.5 & 0.0 & 0.0 \\
Rosa pisocarpa & 0.0 & 0.0 & 0.0 & 0.0 & 0.0 & 0.0 & 0.2 & 0.0 \\
Rubus discolor & 0.0 & 0.0 & 0.0 & 0.0 & 0.0 & 0.7 & 0.0 & 0.0 \\
Rubus parviflorus & 0.0 & 0.0 & 0.1 & 0.0 & 0.0 & 0.0 & 0.9 & 0.5 \\
Rubus ursinus & 0.4 & 0.6 & 0.7 & 0.3 & 0.4 & 1.3 & 1.5 & 0.5 \\
Sambucus racemosa & 0.8 & 0.5 & 1.3 & 0.1 & 0.0 & 0.0 & 0.0 & 0.0 \\
Spiraea douglasii & 0.0 & 0.0 & 0.0 & 0.0 & 0.0 & 0.0 & 0.1 & 0.0 \\
Symphoricarpos albus & 0.2 & 0.0 & 0.1 & 0.0 & 1.9 & 2.6 & 1.8 & 0.5 \\
Vaccinium parvifolium & $\underline{0.1}$ & $\underline{0.0}$ & $\underline{0.0}$ & $\underline{0.0}$ & $\underline{0.0}$ & $\underline{0.0}$ & $\underline{0.0}$ & 0.3 \\
$\quad$ Total & 7.7 & 11.4 & 9.4 & 1.8 & 9.9 & 9.2 & 11.9 & 18.7
\end{tabular}


The basal area histograph of each plant assemblage is shown in Figures 3-10. Coniferous species, such as Pseudotsugamenziesii dominated the mixed coniferous assemblages (Figures 3-6), while hardwoods, such as Fraxinuslatifolia and Quercus garryana, defined community structure in the mixed hardwood assemblages (Figures 7-9). Cluster analysis of the eight plant assemblages, based on basal area data and cover data, grouped the mixed coniferous and mixed hardwood assemblages separately (Figures 11 and 12). The cophenetic correlation coefficients for both analyses were greater than 0.8 , indicating minimal data distortion.

Because there were no observations made of stunted seedlings in the park, it is assumed that trunk diameter is positively correlated with plant age. The diameter class distribution of tree species in each sample is shown in Tables 7-14. Abies grandis, Acer macrophyllum, Thuja plicata, and Tsuga heterophylla were reproducing in the mixed coniferous assemblages (tables 7-10). Abies grandis, Fraxinus latifolia, and Pseudotsuga menziesii were reproducing in the mixed hardwood and shrubland assemblages (Tables 11-14).

Examination of the soil pits dug in each plant assemblage confirmed the designation of each soil type by Green (1982), with one exception. Green (1982) identified the northwest corner of the park as consisting of Aloha silt loam. The soil pit dug in plant assemblage $\mathrm{G}$, indicated that the soil type was more similar to the Amity silt loam in plant assemblage $\mathrm{F}$. 


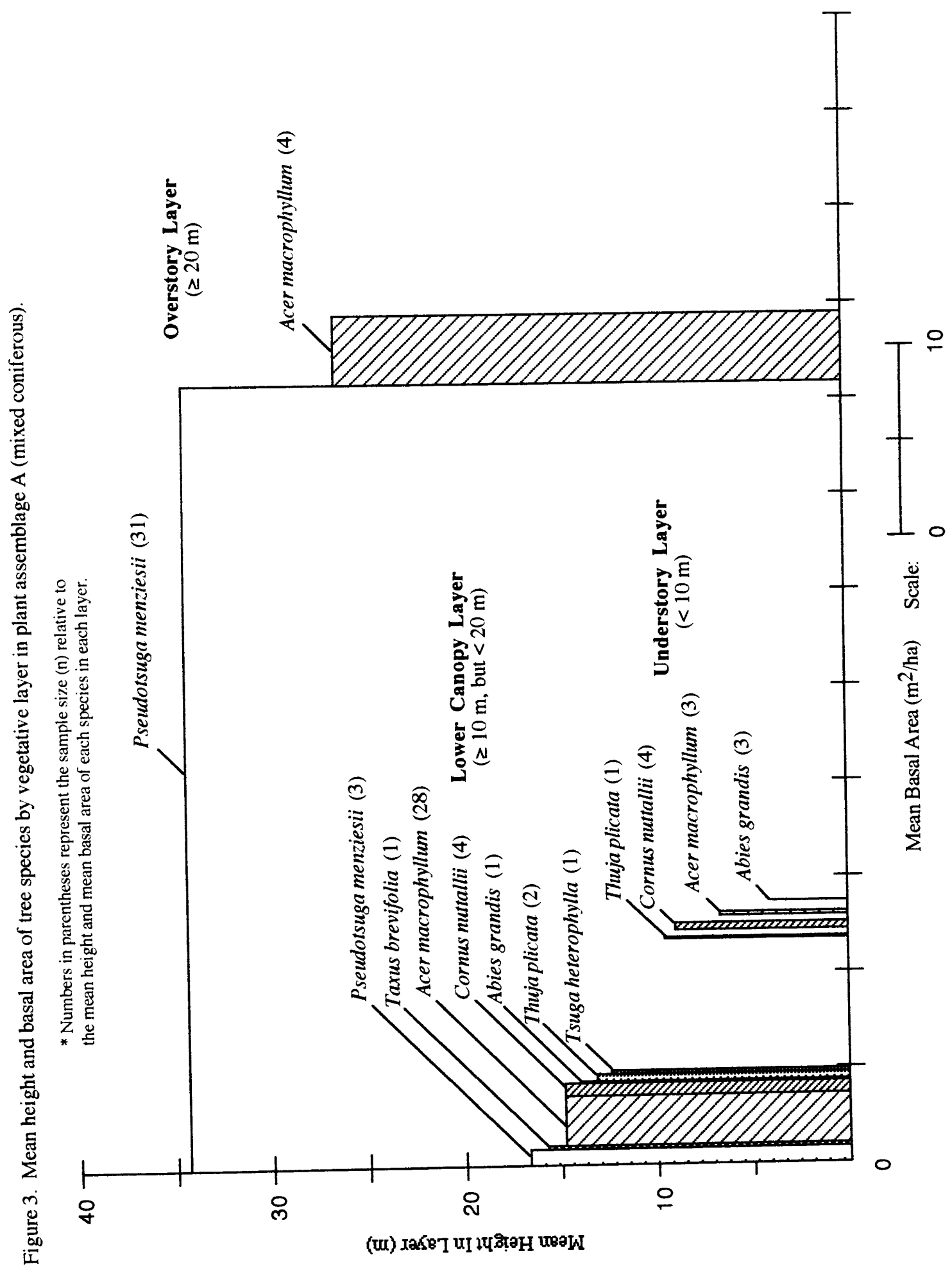




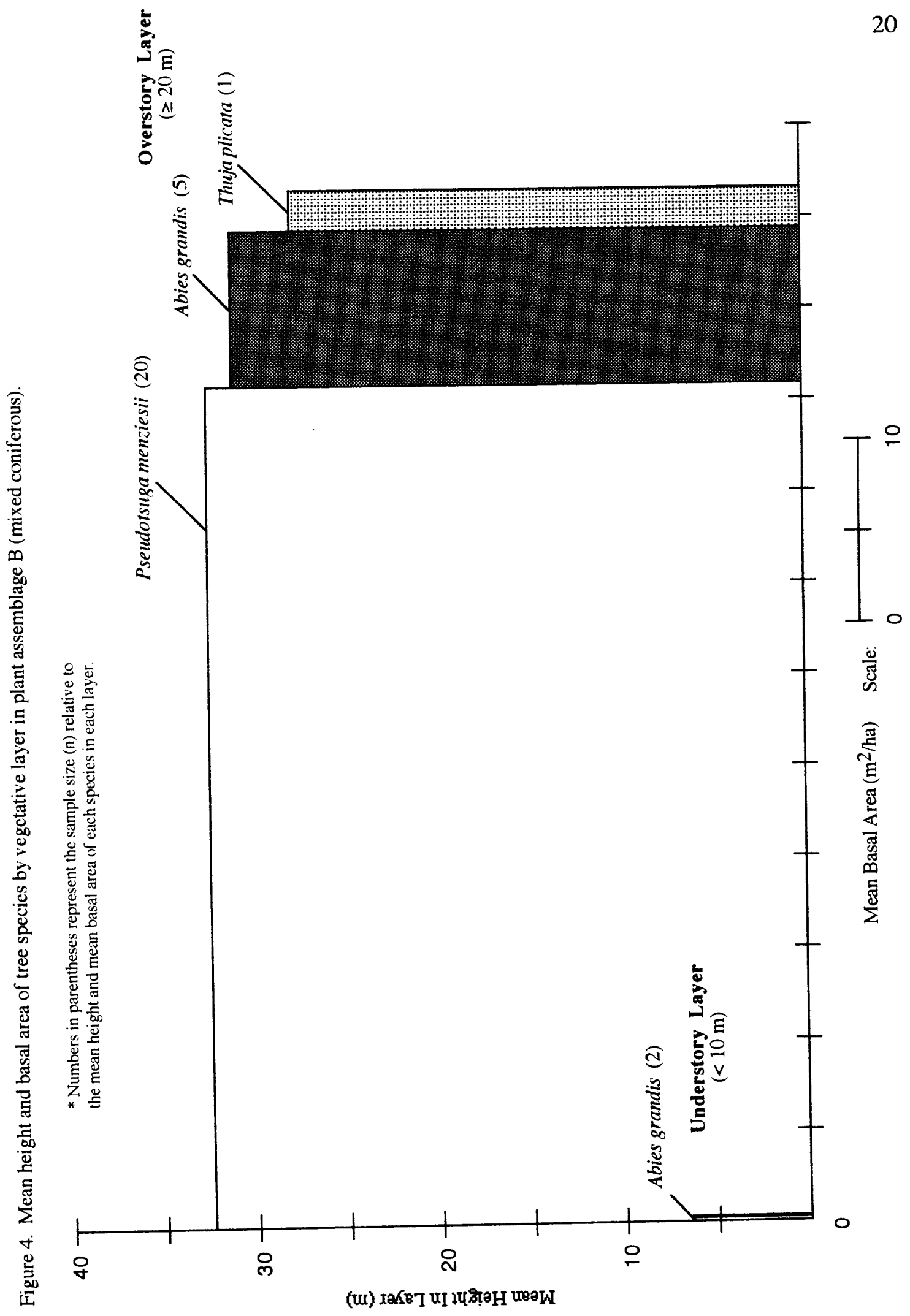




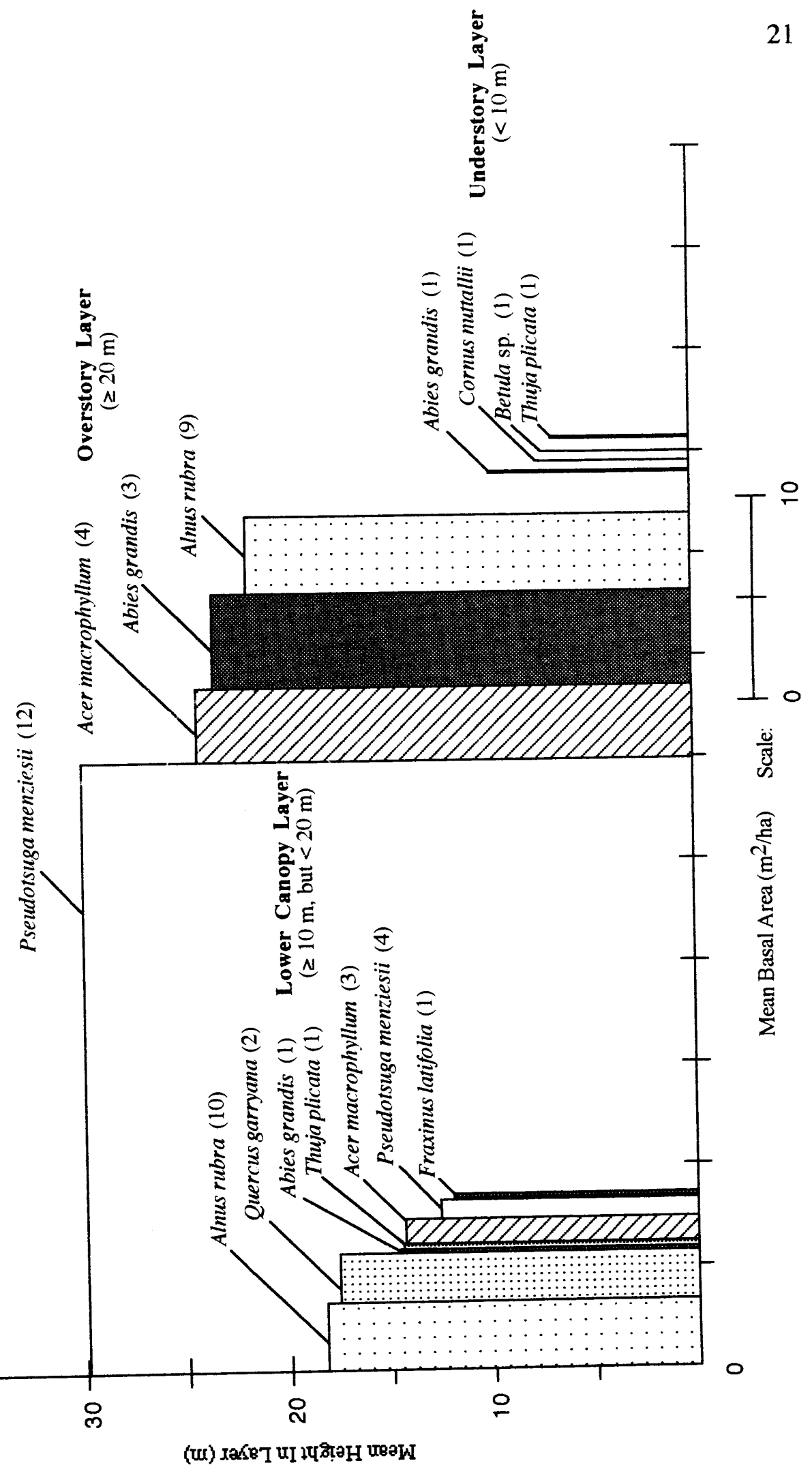




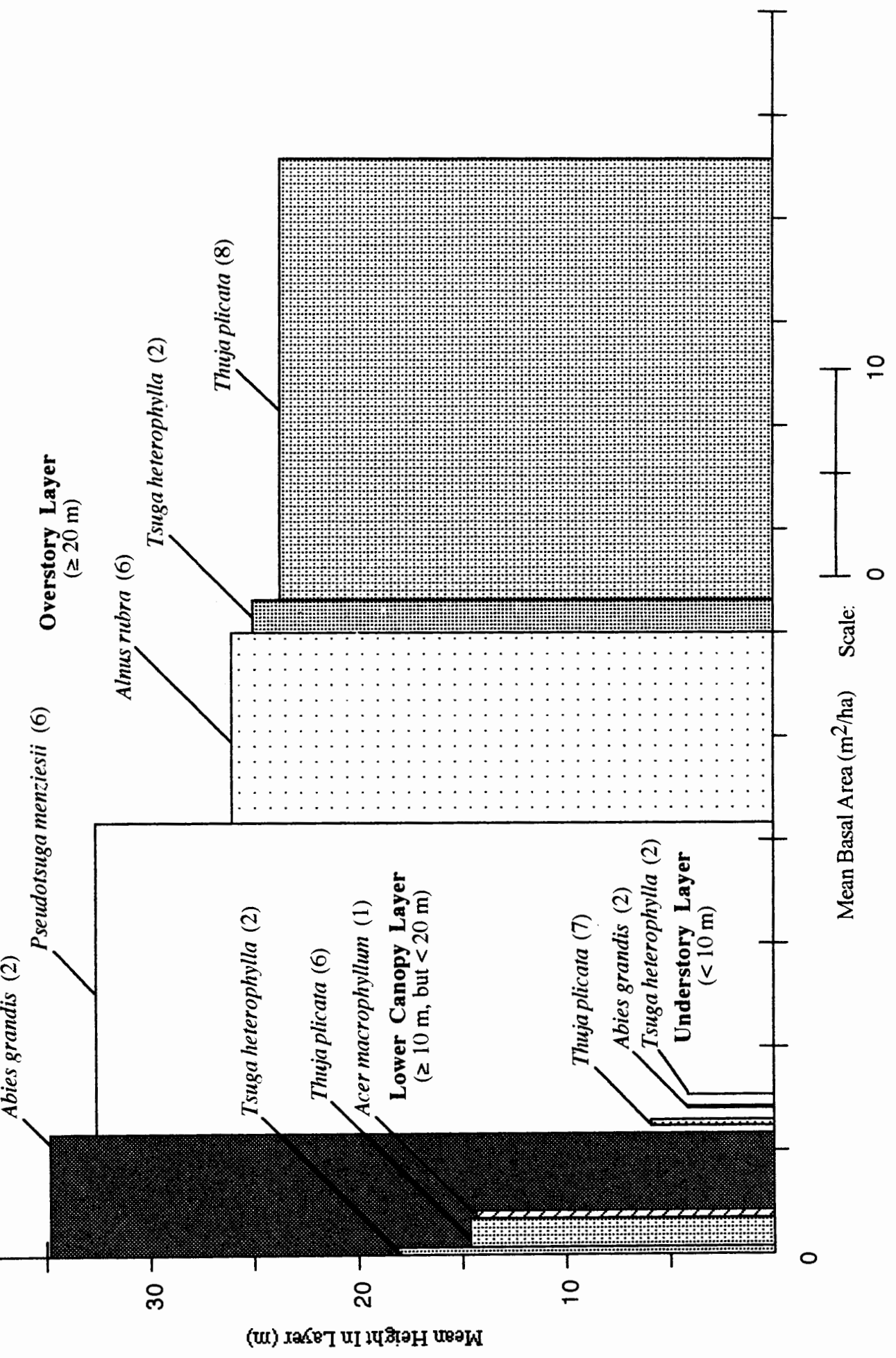




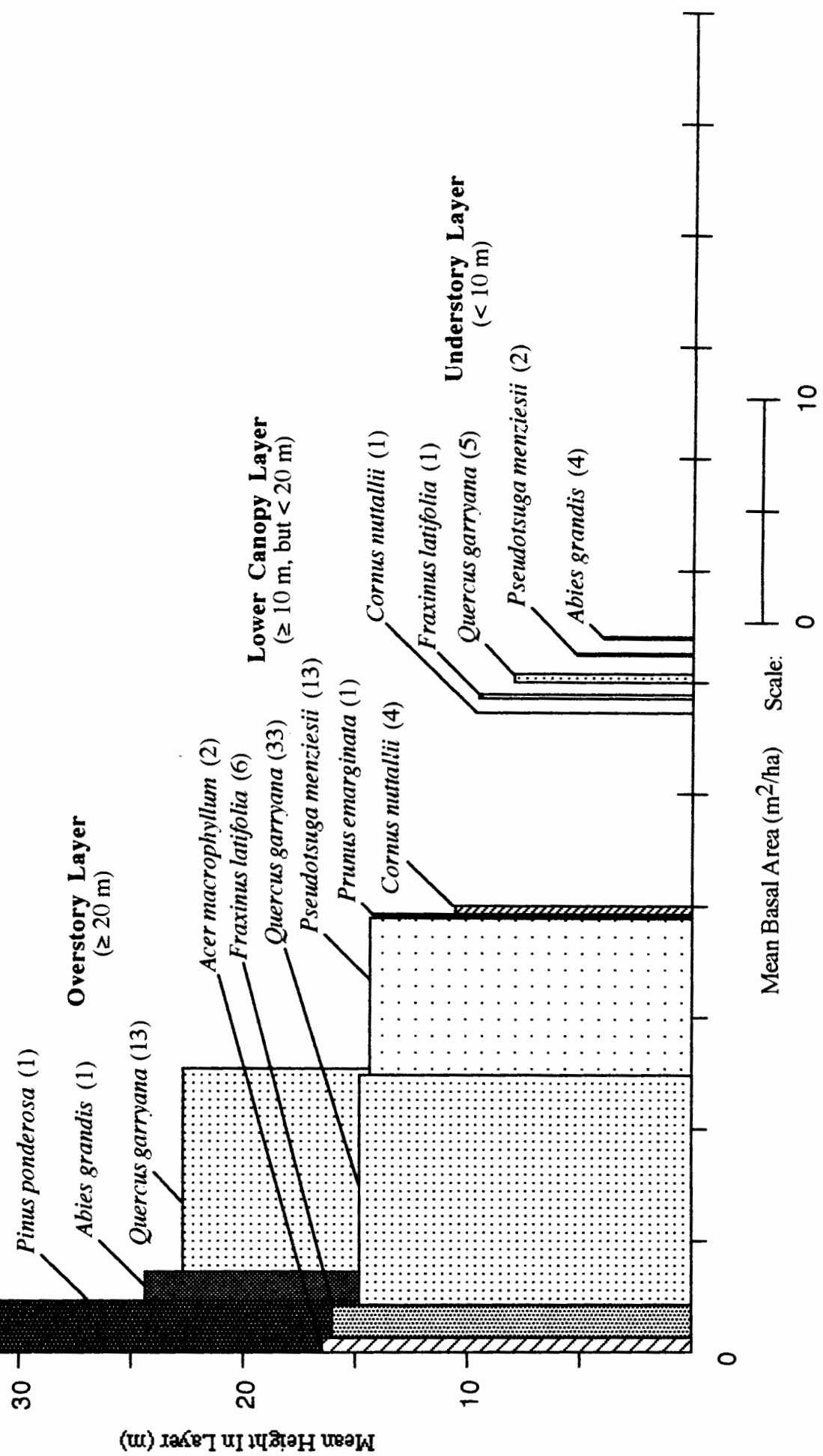



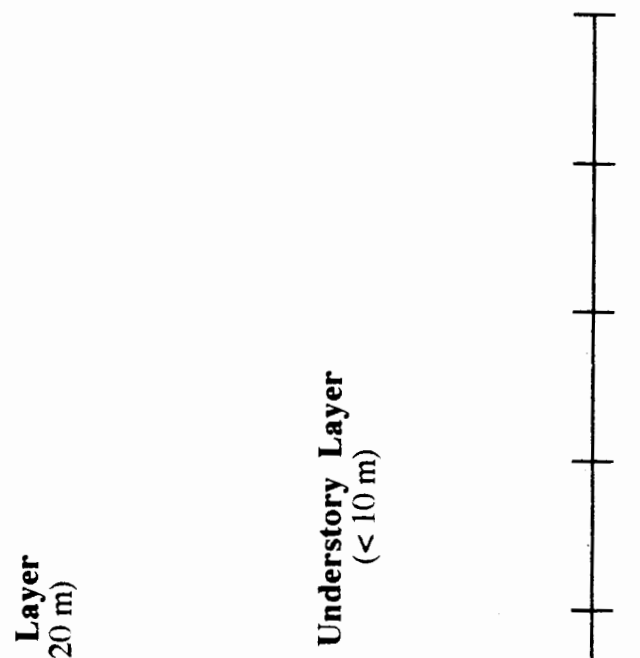

๙ิ

호으

설

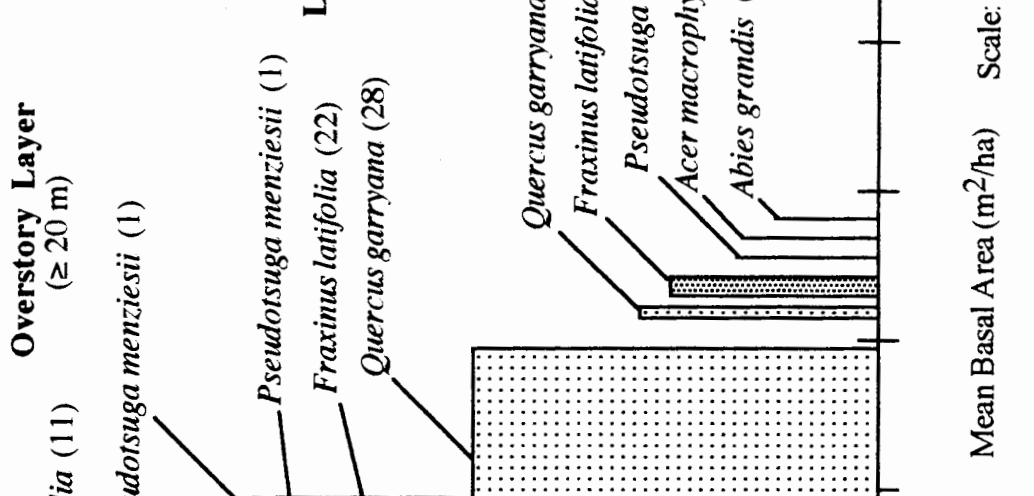

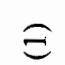

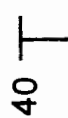

q

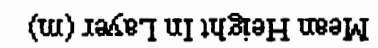



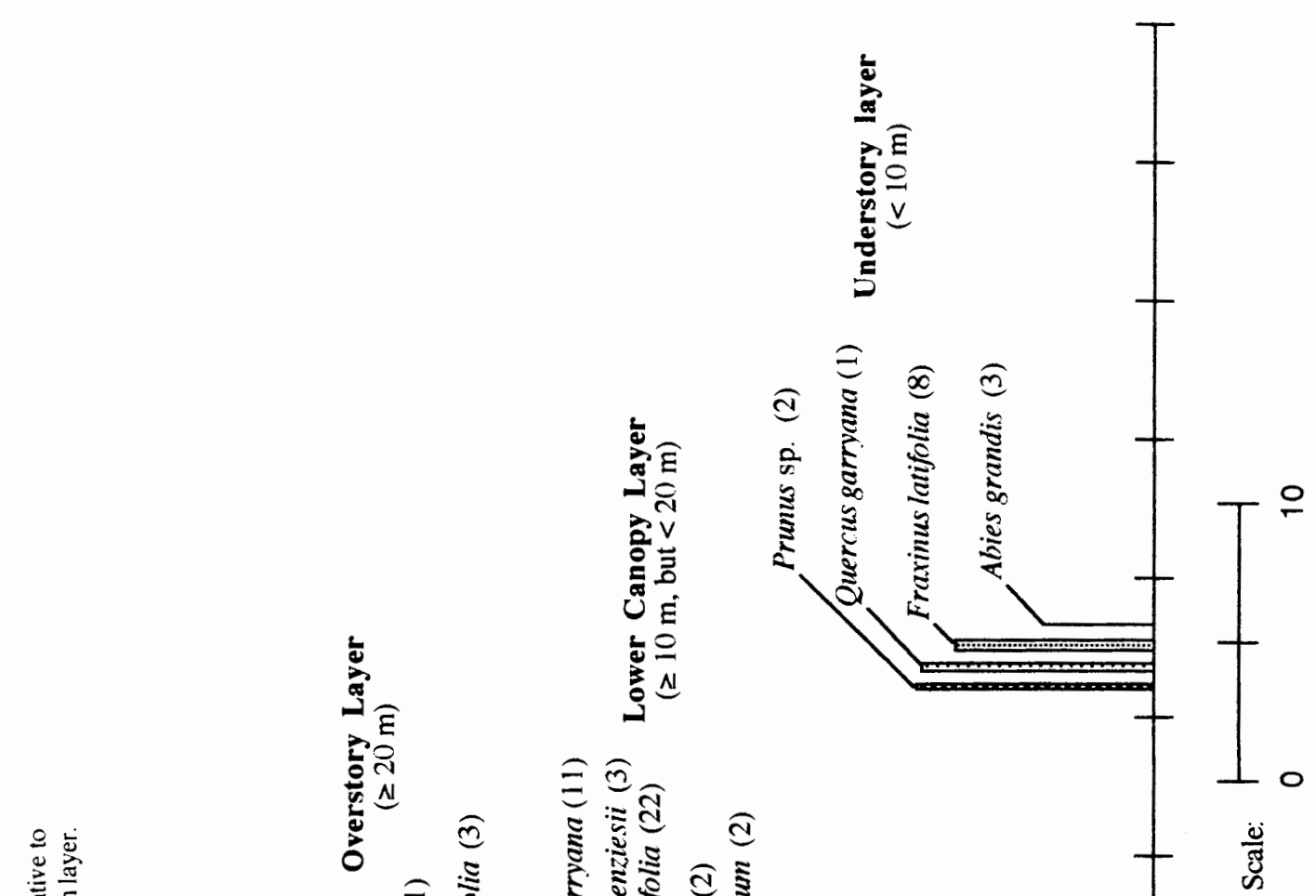

垴

E.

충유

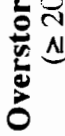

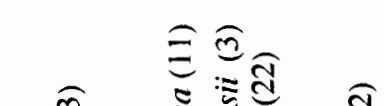

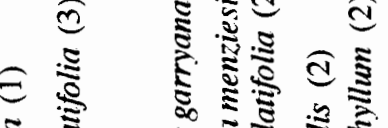

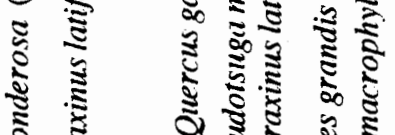

$\frac{\pi}{\tilde{c}}$

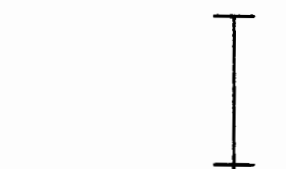

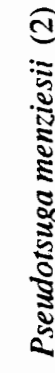

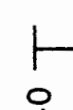

o

돌

*

(ิ)
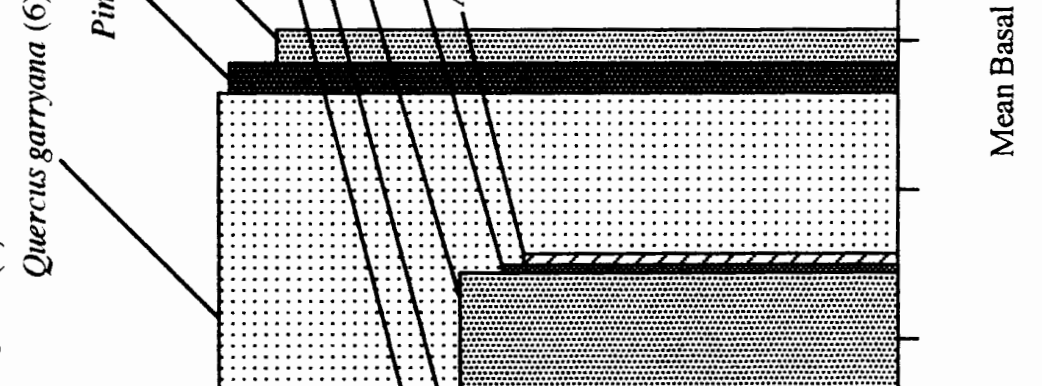

on

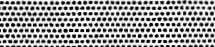

:

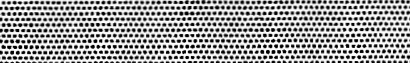

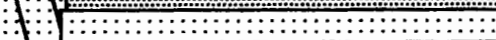
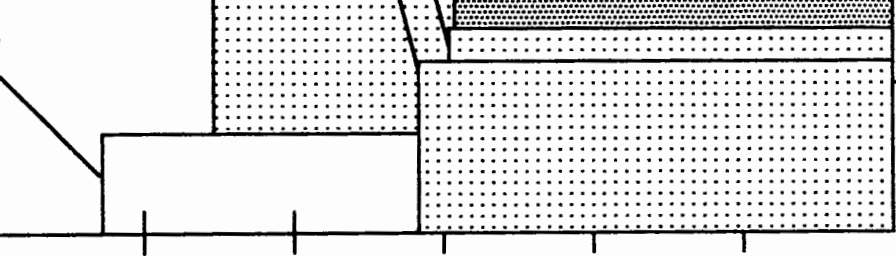

요

요

우

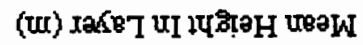



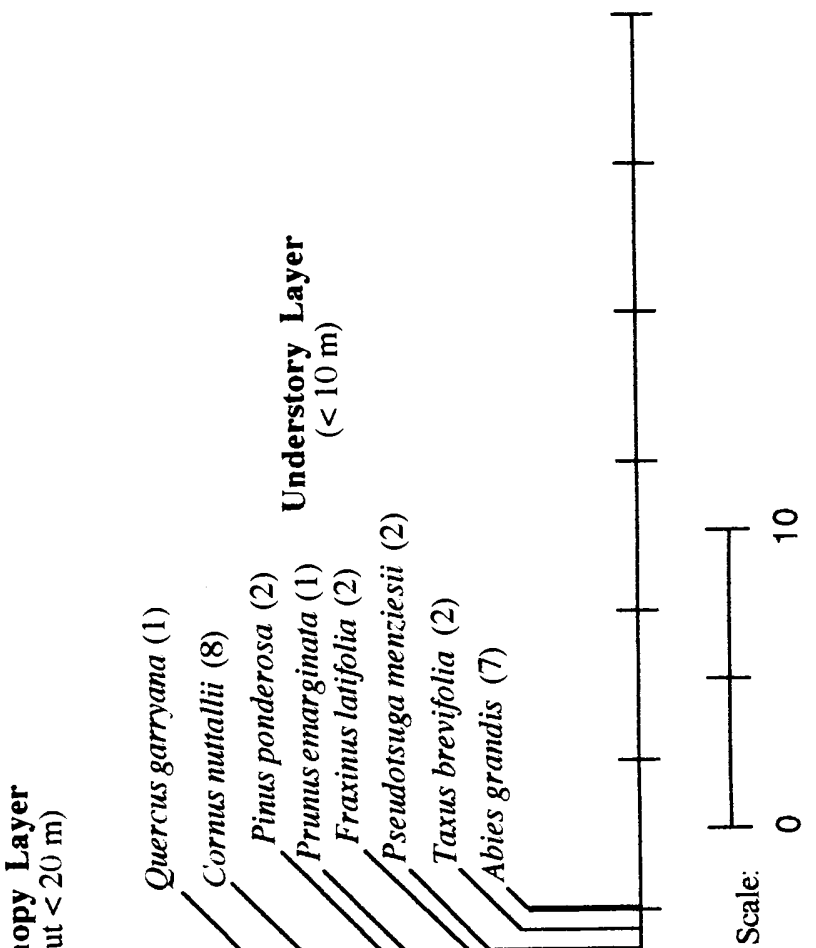

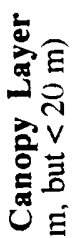

응

신

[IIIIIIIIIIIIII

㿣

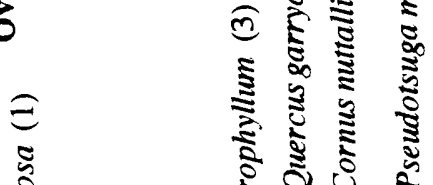

$=\approx$

จ. $:$.

ग)

उ 5

ฐั้

¿

:

20

ป
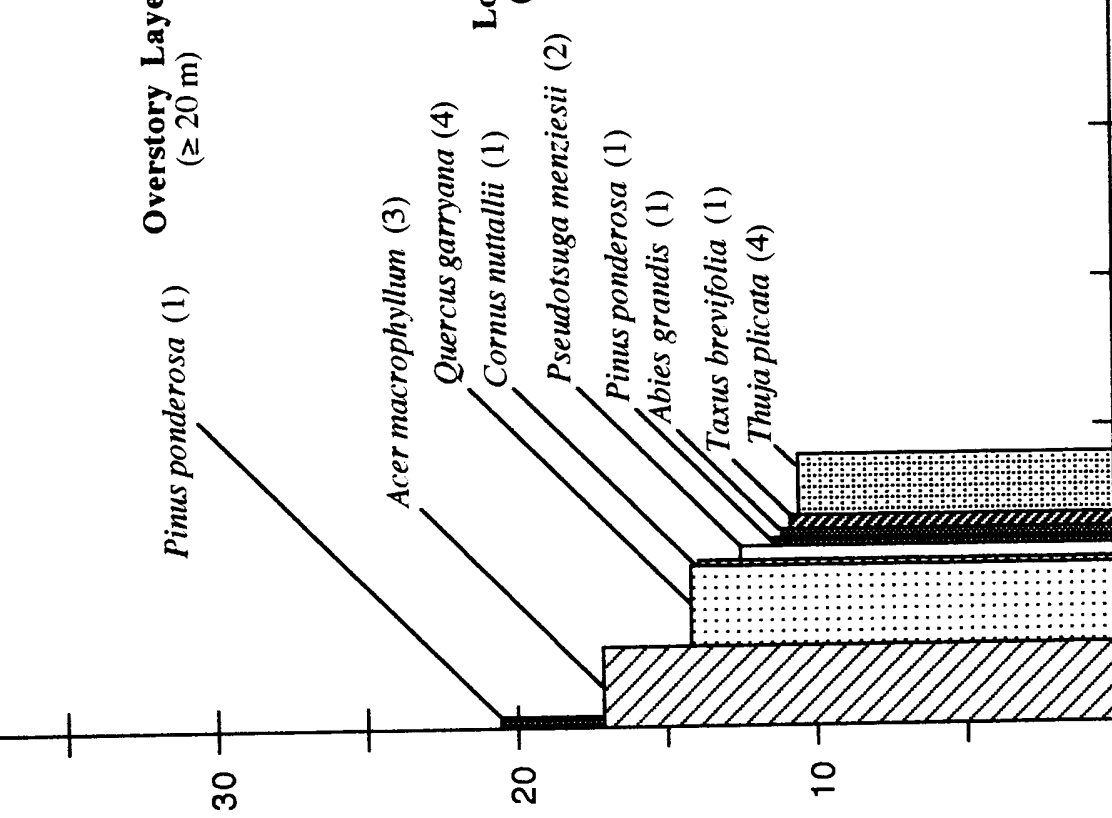

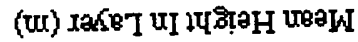


Figure 11. Dendrogram ${ }^{1}$ from the cluster analysis 2 of eight plant assemblages, based on tree basal area data.

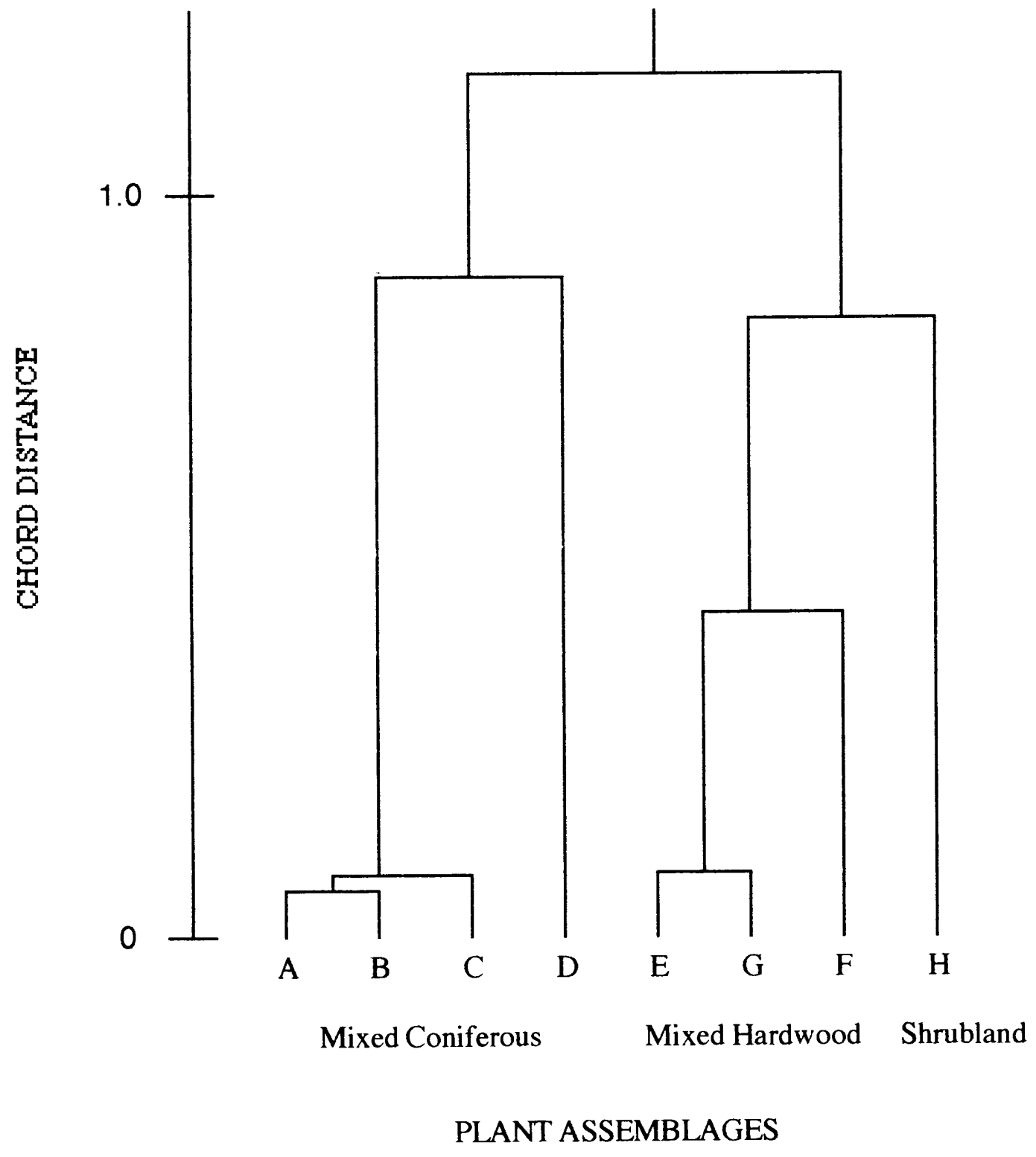

1 Cophenetic correlation coefficient $=0.95$

2 UPGMA clustering method was used. 
Figure 12. Dendrogram ${ }^{1}$ from the cluster analysis ${ }^{2}$ of eight plant assemblages, based on tree and shrub cover data.

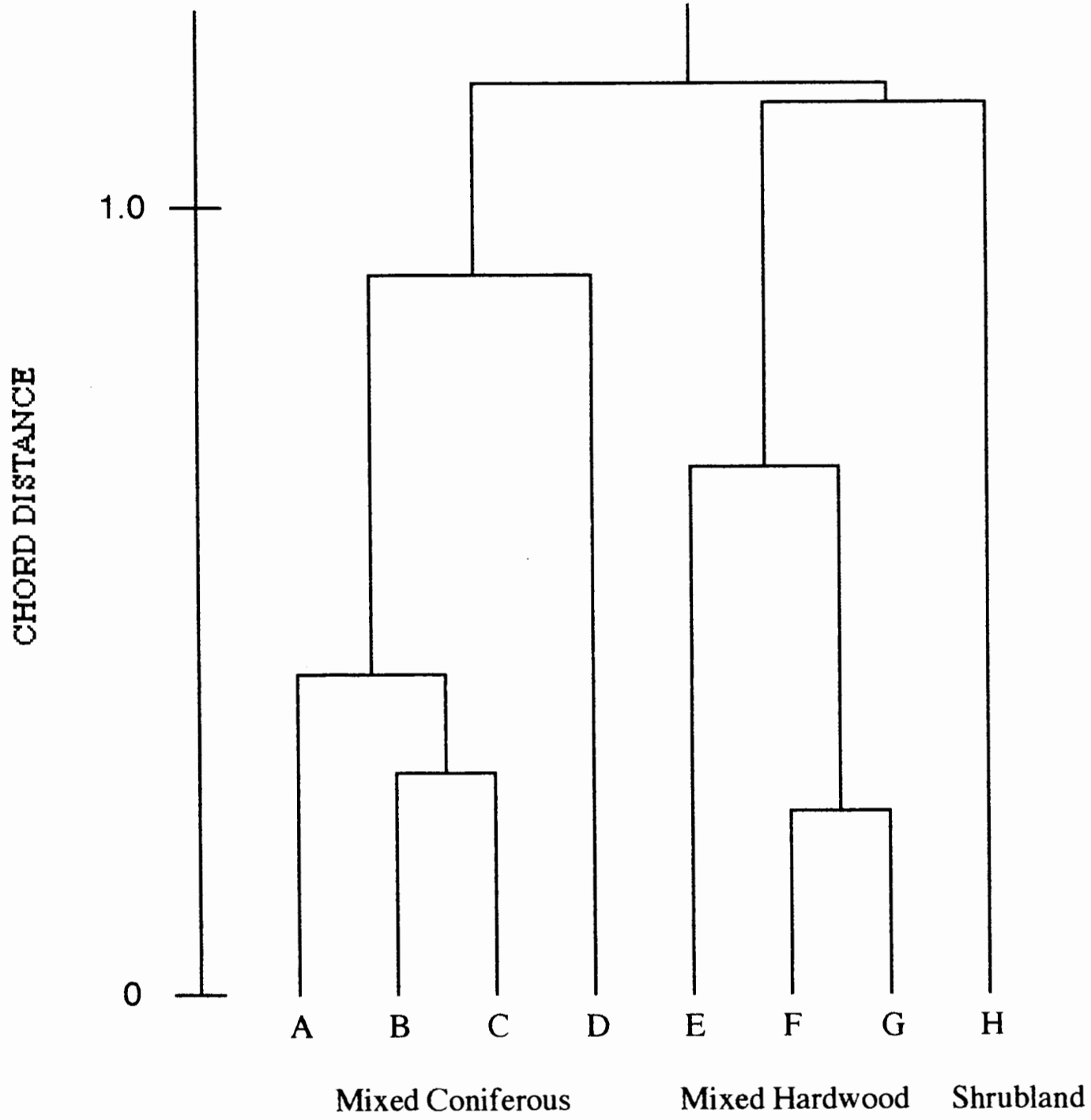

PLANT ASSEMBLAGES

1 Cophenetic correlation coefficient $=0.87$

2 UPGMA clustering method was used. 
Table 7. Number of trees of each species ranked by diameter class in plant assemblage $A$ (mixed coniferous).

\begin{tabular}{lccccccccccc}
\multicolumn{10}{c}{} & \multicolumn{10}{c}{ Diameter Class (cm) } \\
$\quad$ Tree Species & $<2$ & $\geq 5$ & $\geq 10$ & $\geq 20$ & $\geq 30$ & $\geq 40$ & $\geq 50$ & $\geq 60$ & $\geq 70$ & $\geq 80$ \\
Abies grandis & 2 & 1 & 1 & & & & & & & \\
Acer macrophyllum & & 10 & 19 & 2 & 2 & 1 & 1 & & & \\
Cornus nuttallii & & 1 & 6 & 1 & & & & & & \\
Pseudotsuga menziesii & & & 1 & 9 & 5 & 5 & 7 & 3 & 3 & 1 \\
Taxus brevifolia & & 1 & & & & & & & \\
Thuja plicata & & 3 & & & & & & & \\
Tsuga heterophylla & & & & 1 & & & & &
\end{tabular}

Table 8. Number of trees of each species ranked by diameter class in plant assemblage $B$ (mixed coniferous).

Diameter Class $(\mathbf{c m})$

$\begin{array}{lccccccccccc}\text { Tree Species } & <2 & \geq 2 & \geq 5 & \geq 10 & \geq 20 & \geq 30 & \geq 40 & \geq 50 & \geq 60 & \geq 70 & \geq 80 \\ \text { grandis } & 1 & 1 & 1 & & 1 & 1 & & 2 & 1 & & \\ \text { macrophyllum } & 2 & & & & & & & & & & \end{array}$

$\begin{array}{lllllll}\text { Pseudotsuga menziesii } & 1 & 4 & 6 & 2 & 3 & 4 \\ \text { Thuja plicata } & & & & 1 & & \end{array}$

*All ten seedlings occurred in one plot near the edge of assemblage B.

Table 9. Number of trees of each species ranked by diameter class in plant assemblage $C$ (mixed coniferous).

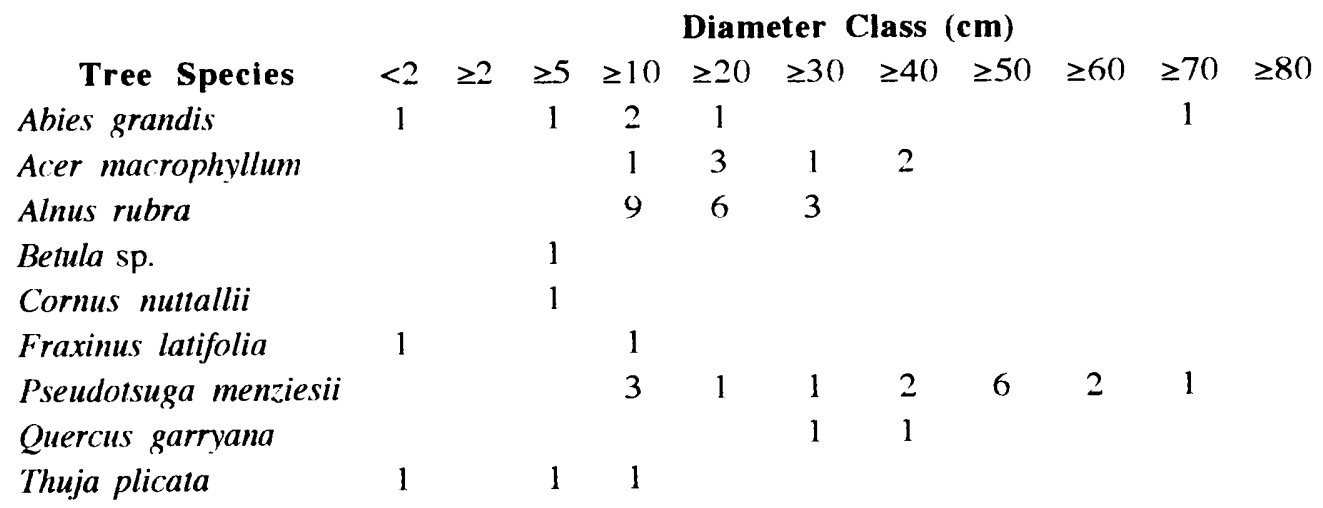


Table 10. Number of trees of each species ranked by diameter class in plant assemblage $D$ (mixed coniferous).

\section{Diameter Class $(\mathbf{c m})$}

$\begin{array}{lccccccccccc}\quad \text { Tree Species } & <2 & \geq 2 & \geq 5 & \geq 10 & \geq 20 & \geq 30 & \geq 40 & \geq 50 & \geq 60 & \geq 70 & \geq 80 \\ \begin{array}{l}\text { Abies grandis } \\ \text { Acer macrophyllum }\end{array} & 2 & 1 & 1 & & & & 1 & & & 1 & \\ \text { Alnus rubra } & & & & & 1 & & & & & \\ \begin{array}{l}\text { Pseudotsuga mensiesii } \\ \text { Thuja plicata }\end{array} & & & & & 2 & 1 & 1 & 1 & 1 & \\ \text { Tsuga heterophylla } & 1 & 1 & 6 & 5 & 2 & 1 & & 2 & 1 & 3 & \\ \end{array}$

Table 11. Number of trees of each species ranked by diameter class in plant assemblage $E$ (mixed hardwood).

\section{Diameter Class $(\mathbf{c m})$}

Tree Species $\quad<2 \quad \geq 2 \quad \geq 5 \quad \geq 10 \quad \geq 20 \quad \geq 30 \quad \geq 40 \quad \geq 50 \quad \geq 60 \quad \geq 70 \quad \geq 80$ Abies grandis Acer macrophyllum Cornus nuttallii Fraxinus latifolia $\begin{array}{lll}1 & 3 & 1\end{array}$

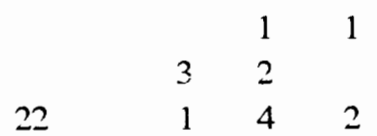

Pinus ponderosa

Prunus emarginala $\begin{array}{llllcccc}\text { Pseudotsuga menziesii } & 1 & 1 & 1 & 4 & 6 & 2 & 1 \\ \text { Quercus garryana } & & & 2 & 21 & 20 & 8 & \end{array}$

Table 12. Number of trees of each species ranked by diameter class in plant assemblage $F$ (mixed hardwood).

Diameter Class $(\mathrm{cm})$

$\begin{array}{lllllllllll}\text { Tree Species } & <2 & \geq 2 & \geq 5 & \geq 10 & \geq 20 & \geq 30 & \geq 40 \quad \geq 50 \quad \geq 60 \quad \geq 70 \quad \geq 80\end{array}$ Abies grandis Acer macrophyllum Fraxinus latifolia $\begin{array}{lll}11 & 2 & 1\end{array}$

Pinus ponderosa $\begin{array}{llllll}12 & 3 & 5 & 18 & 11 & 5\end{array}$

$\begin{array}{lllllllll}\text { Psuedotsuga menziesii } & 1 & 1 & & & & 2 & \\ \text { Quercus garryana } & & & 13 & 13 & 2 & 2\end{array}$


Table 13. Number of trees of each species ranked by diameter class in plant assemblage $G$ (mixed hardwood).

\section{Diameter Class (cm)}

\begin{tabular}{|c|c|c|c|c|c|c|c|c|c|c|}
\hline Tree Species & $<2$ & $\geq 2$ & $\geq 5$ & $\geq 10$ & $\geq 20$ & $\geq 30$ & $\geq 40$ & $\geq 50$ & $\geq 60$ & $\geq 70$ \\
\hline Abies grandis & & 2 & 1 & 2 & & & & & & \\
\hline Acer macrophyllum & 1 & & & 2 & & & & & & \\
\hline Fraxinus latifolia & 4 & 3 & 2 & 20 & 7 & 1 & & & & \\
\hline Pinus ponderosa & & & & & & 1 & & & & \\
\hline Prunus sp. & & & 1 & 1 & & & & & & \\
\hline Pseudotsuga menziesii & & & & 1 & 2 & & 1 & 1 & & \\
\hline Quercus garryana & & & 2 & 2 & 6 & 4 & & 2 & & 2 \\
\hline
\end{tabular}

Table 14. Number of trees of each species ranked by diameter class in plant assemblage $H$ (shrubland).

Diameter Class (cm)

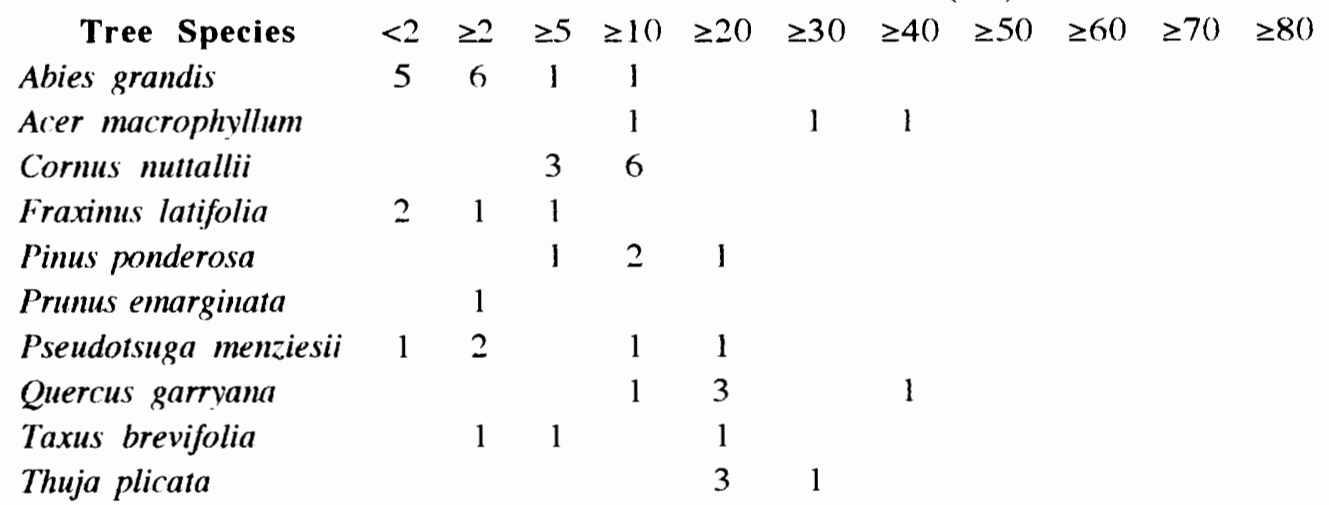




\section{DISCUSSION}

Four of the original eight plant assemblages were designated as mixed coniferous and seemed to constitute a relatively natural group, each dominated by conifers (Figures 3-6). They were characterized by the tree species Abies grandis, Acer macrophyllum, Alnus rubra, Pseudotsuga menziesii, Thuja plicata, and Tsuga heterophylla (Tables 1-4) and the shrub species Acer circinatum, Berberis nervosa, and Sambucus racemosa (Tables 5 and 6). Cluster analysis, whether based on basal area or cover data, grouped the mixed coniferous plant assemblages together (Figures 11 and 12). In both applications of cluster analysis, plant assemblage D was least similar to the other mixed coniferous assemblages. This apparent ecological distance between plant assemblage $\mathrm{D}$ and the other mixed coniferous assemblages was due to the prominence of Thuja plicata in assemblage D. Whether Thuja plicata increases due to a difference in physical factors, biotic interactions, or disturbance history is not clear. The location of plant assemblage D near the confluence of Cedar Mill Creek and Beaverton Creek suggests that the prominence of Thuja plicata is a response to relatively mesic conditions.

Three of the remaining four plant assemblages were designated as mixed hardwood, each dominated by hardwoods (Figures 7-9). They were characterized by the tree species Fraxinus latifolia and Quercus garryana (Tables 1-4) and the shrub species Amelanchier alnifolia, Rhamnus purshiana, and Symphoricarpos albus (Tables 5 and 6). Cluster analysis also grouped the mixed hardwood assemblages together (Figures 11 and 12). Assemblage $G$ varied relative to $E$ and $F$ between the two dendrograms. E and $\mathrm{G}$ were more similar in the cluster analysis based on tree basal area, while $\mathrm{F}$ and $\mathrm{G}$ were more similar in the analysis based on tree and shrub cover. 
The grouping of $E$ and $G$ based on basal area was due to the larger basal area of Quercus garryana in assemblages $\mathrm{E}$ and $\mathrm{G}$ and Fraxinus latifolia in assemblage F (Table 1). The grouping of $F$ and $G$ based on cover was due to the larger cover of Fraxinus latifolia in assemblages F and G and Pseudotsuga menziesii and Quercus garryana in assemblage E (Table 4).

The grouping of the shrubland by itself is more tenuous than the grouping of the mixed coniferous and mixed hardwood plant assemblages. The shrubland was distinguished from the other plant assemblages in having the smallest total tree basal area and coverage (Tables 1 and 4) and the largest total shrub coverage (Table 6). Cluster analysis grouped the shrubland with the mixed hardwood assemblages, based on basal area (Figure 11), but clustered it separately when based on cover data (Figure 12). Based on its current physiognomy, the shrubland should be grouped separately from the mixed hardwood assemblages. The shrubland was the most recently disturbed plant assemblage and is in a relatively early stage of successional development. It will most likely undergo the most rapid change.

Tree establishment was occurring in each of the areas studied. In the mixed coniferous plant assemblages, seedlings of Abies grandis, Acer macrophyllum, Thuja plicata, and Tsuga heterophylla were growing (Tables 7-10). In the mixed hardwood and shrubland plant assemblages Abies grandis, Fraxinus latifolia, and Pseudotsuga menziesii were reproducing (Tables 11-14). Fraxinus latifolia and Pseudotsuga menziesii are classified as intermediate in their tolerance of shade (Burns and Honkala 1990, Randall et al. 1990) and need high light conditions to germinate and establish. Abies grandis, Acer macrophyllum, Thuja plicata, and Tsuga heterophylla are more shade tolerant (Burns and Honkala 1990, Randall et al. 1990). The differential pattern of reproduction among the various plant assemblages suggests 
the regeneration of different groups of species is primarily due to light requirements for germination and seedling establishment. This hypothesis is supported by the occurrence of shade intolerant seedlings growing in open patches of the light-limited, mixed coniferous assemblages. It is not clear whether other abiotic factors, biotic interactions, or disturbance history also affect this pattern of seedling establishment; however, my observations to date show no strong correlation between any of these factors and seedling occurrence.

There are several different soil types in the park (Green 1982). My evaluation of soil types in the park was only cursory, but to the extent examined the mixed coniferous plant assemblages occurred on Aloha silt loam. The mixed hardwood and shrubland plant assemblages occurred on Amity silt loam, Dayton silt loam, or Huberly silt loam. These last three soil types are more clayey, wetter, and more poorly drained soils, relative to the Aloha silt loam soil type. Higher, clay-perched water tables cause the higher moisture levels of the Amity, Dayton, and Huberly soil types (Green 1982). Due to the prominence of the conifers only on the better drained soils, the plant assemblages could remain distinct indefinitely. Based on similarities in soil type and successional trends, the shrubland is likely to become more like the mixed hardwood assemblages.

Although the results of this study support a relatively natural grouping of the eight plant assemblages into two associations (mixed coniferous and mixed hardwood), each assemblage has a unique character. Each plant assemblage is relatively homogeneous, with narrow ecotones. This pattern suggests that each plant assemblage is responding to a particular complex of biotic and abiotic interactions, as well as to a unique disturbance history, rather than merely reflecting the outcome of chance. 
There is a long history of intense disturbance affecting vegetation in the Willamette Valley. This disturbance history includes regular burning by Native Americans (Habeck 1961, Johannessen et al. 1971) and more recently, fire prevention, clearing, logging, grazing, and urban development (Towle 1982, Franklin and Dyrness 1973). The vegetation in Tualatin Hills Nature Park has probably been subjected to most of these disturbances.

Within the framework of this disturbance history, the species composition and structure of the woodland vegetation in Tualatin Hills Nature Park are typical of the Willamette Valley. The predominant plant species in the sampled plant assemblages are typical of the assumed pre-European Willamette Valley vegetation (Habeck 1961, Johannessen et al. 1971). Mixed hardwood and coniferous woodlands are the expected vegetation types under the current condition of fire suppression (Franklin and Dymess 1973).

It is likely that portions of the park were more open in the past, possibly existing as prairies or oak savannas (Habeck 1961, Johannessen et al. 1971). This possibility is suggested by the presence of large, remnant Pinus ponderosa and widecrowned Quercus garryana in the mixed hardwood plant assemblages. The presence of these remnant trees may represent the elimination of open woodlands and the formation of denser stands due to fire suppression (Habeck 1961, Thilenius 1968, Franklin and Dyrness 1973).

Successional trends in Tualatin Hills Nature Park also seem to parallel those typical of vegetation in the Willamette Valley (Sprague and Hansen 1946, Cole 1977, Towle 1982, Franklin and Dyrness 1973), with hardwoods functioning as pioneer species in plant communities that develop into hardwood-conifer mixtures. The ubiquitous reproduction of Abies grandis in the park supports the hypothesis that it is 
the predicted climax in the Willamette Valley under the current condition of fire suppression (Franklin and Dyrness 1973). Any major change in the park's woodland vegetation would occur over several hundreds of years. 


\section{REFERENCES}

Bonham, C. D. 1989. Measurements for Terrestrial Vegetation. John Wiley \& Sons, New York.

Burns, R. M. and B. H. Honkala. 1990. Silvics of North America. Vol. 1 \& 2, Agriculture Handbook 654, Forest Service, United States Department of Agriculture, Washington, D.C.

Cole, D. 1977. Ecosystem dynamics in the coniferous forest of the Willamette Valley, Oregon, U.S.A. Journal of Biogeography 4:181-192.

Franklin, J. F. and C. T. Dyrness. 1973. Natural Vegetation of Oregon and Washington. USDA Forest Service, General Technical Report PNW-8. Pacific Northwest Forest and Range Experiment Station, Portland, Oregon.

Green, G. L. 1982. Soil Survey of Washington County, Oregon. Soil Conservation Service, United States Department of Agriculture, in cooperation with the Oregon Agricultural Experiment Station.

Habeck, J. R. 1961. The original vegetation of the Mid-Willamette Valley, Oregon. Northwest Science 35:65-77.

Hitchcock, C. L. and A. Cronquist. 1973. Flora of the Pacific Northwest. University of Washington Press, Seattle, Washington.

Johannessen, C. L., W. A. Davenport, A. Millet, and S. McWilliams. 1971. The vegetation of the Willamette Valley. Annals of the Association of American Geographers 61:286-302.

Jones \& Jones: Architects \& Landscape Architects. 1984. Regional Park Master Plan. Prepared for Tualatin Hills Park \& Recreation District by Jones \& Jones.

Kurahashi \& Associates, Inc. 12600 S.W. 72nd Avenue, Suite 100, Tigard, Oregon. 
Ludwig, J. A. and J. F. Reynolds. 1988. Statistical Ecology, a Primer on Methods and Computing. John Wiley \& Sons, Inc., New York.

McKinstry, M. 1983. Historical Notes: Regional Park Site, St. Mary's Woods.

Obtained from Tualatin Hills Park \& Recreation District.

Podani, J. 1993. SYN-TAX Computer Programs for Multivariate Data Analysis in Ecology and Systematics, Version 5.0. Scientia Publishing, Budapest, Hungary.

Pojar, J. and A. MacKinnon. 1994. Plants of the Pacific Northwest Coast, Washington, Oregon, British Columbia \& Alaska. Lone Pine Publishing, Redmond, Washington.

Randall, W. R., R. F. Keniston, D. N. Bever, and E. C. Jensen. 1990. Manual of Oregon Trees and Shrubs. Oregon State University Book Stores, Inc. Corvallis, Oregon.

Romesburg, H. C. 1984. Cluster Analysis for Researchers. Lifetime Learning Publications, Belmont, California.

Sprague, F. L. and H. P. Hansen. 1946. Forest succession in the McDonald Forest, Willamette Valley, Oregon. Northwest Science 20:89-98.

Thilenius, J. 1968. The Quercus garryana forest of the Willamette Valley. Ecology 49:1224-33.

Towle, J. 1974. Woodland in the Willamette Valley: an Historical Geography. Unpublished Ph.D. dissertation, University of Oregon.

Towle, J. C. 1982. Changing geography of Willamette Valley woodlands. Oregon Historical Quarterly 83:66-87. 


\begin{abstract}
APPENDIX
Species listed by designated growth form, nomenclature follows

Hitchcock and Cronquist (1973)
\end{abstract}

Trees

Scientific Name

Abies grandis

Acer macrophyllum

Alnus rubra

Betulasp.

Cornus nuttallii

Fraxinus latifolia

Pinus ponderosa

Prunus emarginata

Prunus sp.

Pseudotsuga menziesii

Quercus garryana

Taxus brevifolia

Thuja plicata

Tsuga heterophylla
Common Name

grand fir

bigleaf maple

red alder

birch sp.

Pacific dogwood

Oregon ash

ponderosa pine

bitter cherry

cherry $\mathrm{sp}$.

Douglas-fir

Oregon white oak

Pacific yew

western redcedar

western hemlock 
Shrubs

Scientific Name

Acer circinatum

Amelanchier alnifolia

Berberis aquilfolium

Berberis nervosa

Corylus cornuta var. californica

Cornus stolonifera

Crataegus douglasii

Crataegus monogyna

Gaultheria shallon

Hedera helix

Holodiscus discolor

Ilex aquilfolium

Lonicera sp.

Oemleria cerasiformis

Physocarpus capitatus

Rhamnus purshiana

Rhus diversiloba

Ribes lacustre

Rosa gymnocarpa

Rosa nutkana

Rosa pisocarpa

Rosa sp.

Rubus discolor

Rubus parviflorus

Rubus ursinus

Sambucus racemosa

Spiraea douglasii

Symphoricarpos albus

Vaccinium parvifolium
Common Name

vine maple

serviceberry

tall Oregon-grape

dwarf Oregon-grape

California hazel

red-osier dogwood

black hawthorn

common hawthorn

salal

English ivy

ocean spray

English holly

honeysuckle

osoberry

ninebark

cascara

poisonoak

prickly currant

baldhip rose

Nootka rose

clustered wild rose

rose $\mathrm{sp}$.

Himalayan blackberry

thimbleberry

wild blackberry

red elderberry

hardhack

snowberry

red huckleberry 